2014

\title{
The Aftermath of Catastrophes: Valuing Business Interruption Insurance Losses
}

Chris French

Penn State Law

Follow this and additional works at: http://elibrary.law.psu.edu/fac_works

Part of the Law Commons

\section{Recommended Citation}

source:https://works.bepress.com/chris_french/9

This Article is brought to you for free and open access by the Faculty Works at Penn State Law eLibrary. It has been accepted for inclusion in Journal Articles by an authorized administrator of Penn State Law eLibrary. For more information, please contact ram6023@psu.edu. 


\title{
THE AFTERMATH OF CATASTROPHES: VALUING BUSINESS INTERRUPTION INSURANCE LOSSES
}

\section{Christopher C. French ${ }^{*}$}

\begin{abstract}
With the onslaught of tornadoes, hurricanes, and floods in recent years, business interruption losses have been staggering. Many businesses do not survive such catastrophes. Even business owners that purchased business interruption insurance, which is intended to ensure that a business's revenue stream continues during an interruption in its operations, often find that their insurers have dramatically different views regarding the amount of the losses that should be reimbursed. The reason for this disparity in views is that the loss valuation provisions in business interruption insurance policies provide very little guidance regarding how business interruption losses should be calculated. Thus, disputes regarding the valuation of business interruption losses frequently arise and courts and juries are forced to resolve such disputes with widely varying, inconsistent, and unpredictable results. This lack of predictability has placed a burden on the legal system because far more business interruption cases are tried than are necessary.

This Article analyzes the origins and purpose of business interruption insurance, as well as the courts' inconsistent interpretations of the standard form business interruption loss valuation provisions. The Article then offers an interpretation of the existing loss valuation provisions under the rules of policy interpretation and considers whether the result would be different if

* Christopher C. French is a Visiting Assistant Professor at the University of Pittsburgh School of Law; J.D., Harvard Law School; B.A., Columbia University. The author gratefully acknowledges the legal research contributions of Amanda Lusk to this article. The author also would like to thank Daniel Schwarcz, Jim Chen, and all of the participants in a workshop at Villanova Law School for providing thoughtful comments on earlier drafts of this article.
\end{abstract}


the language were analyzed from a product liability perspective in light of the fact that policies are non-negotiated contracts of adhesion sold on a take-it-or-leave-it basis. The Article concludes with an analysis of the public policy considerations related to the payment of business interruption insurance losses and proposes alternative loss valuation formulas to be used in the future that should provide for consistent, fair and predictable loss valuations and payment of claims without litigation.

\section{TABLE OF CONTENTS}

INTRODUCTION .463

I. ReleVAnt Policy LANGUAGE

A. The Origins of Business Interruption Insurance.

B. The Policy Language Regarding the Valuation of Business Interruption Losses....

II. COURTS' InTERPRETATION AND APPLICATION OF THE POLICY

LANGUAGE REGARDING THE VALUATION OF BUSINESS

INTERRUPTION LOSSES

A. Courts That Have Interpreted the Loss Valuation Language to Allow for Consideration of Only Historical Financial Data

B. Courts That Have Interpreted the Loss Valuation Language to Allow for the Consideration of Local Economic Conditions Post-Catastrophe....

C. Courts' Inconsistent Holdings Regarding the Application of the Loss Valuation Language

D. Courts' Confusion Regarding the Evidentiary Standard Under Which Business Interruption Losses Must be Proven

III. PRINCIPLES OF INSURANCE POLICY INTERPRETATION RELEVANT TO VALUING BUSINESS INTERRUPTION LOSSES.

A. The Doctrine of Contra Proferentem....

B. The "Reasonable Expectations" Doctrine.

C. Construction of the Policy as a Whole

IV. How BUSINESS INTERRUPTION LOSSES SHOULD BE VALUED ...496

A. The Problems with the Existing Framework. 
1. Business Interruption Loss Valuations are Inherently Speculative so They Cannot be Proven with "Reasonable Certainty".

2. Using Only the Policyholder's Historical Financial Information to Value Business Interruption Losses Ignores Some of the Valuation Policy Language....

3. Consideration of the Post-Catastrophe Economic Conditions Can Lead to Unfair Results and Factual Disputes That Must be Tried....

B. How Business Interruption Losses Should be Valued

Under the Existing Policy Language.

1. Applying the Rules of Policy Interpretation to Loss Valuation Language ...

2. Analyzing the Loss Valuation Policy Language as a "Defective Product". 508

C. Proposed Loss Valuation Formulas That are Based Upon the Original Purpose of Business Interruption Insurance and Which Provide Consistent, Predictable Results and the Efficient Resolution of Claims

1. A Stated Daily Loss Value Set Forth in the Policy or Only the Policyholder's Prior Three Years of Historical Earnings and Expenses Should be Used When Valuing Business Interruption Losses.................511

2. Public Policy Considerations .....................................515

\section{INTRODUCTION}

Business interruption losses caused by natural and unnatural disasters are enormous. For example, the business interruption losses associated with the 9/11 terrorist attack have been estimated to exceed $\$ 10$ billion. ${ }^{1}$ Hurricane Katrina caused more than $\$ 45$ billion in damage. ${ }^{2}$ The governors of New York and New Jersey estimated that Hurricane Sandy caused more than $\$ 60$ billion in damages. ${ }^{3}$

1. DANiEl T. TORPey, DANiEl G. LentZ \& Allen Melton, Business InTERruption: COVERAGe, Claims, AND ReCOVERY 4 (2d ed. 2011).

2. Gregory D. Miller \& Joseph D. Jean, Effect of Post-Loss Economic Factors in Measuring Business Interruption Losses: An Insured's and Insurer's Perspectives, in NEW APPLEMAN ON INSURANCE: CURRENT CRITICAL ISSUES IN INSURANCE LAW 25, 25 (2010).

3. Editorial, Hurricane Sandy's Rising Costs, N.Y. TIMES, Nov. 28, 2012, at A32. 
Many businesses impacted by such disasters never recover. Indeed, the United States Department of Labor has estimated that $40 \%$ of businesses never reopen after experiencing a disaster. ${ }^{4}$ Of those that do, at least $25 \%$ fail within two years. ${ }^{5}$

Now imagine a business owner in an area that was just struck by a flood, tornado, or hurricane. The business was damaged such that operations had to be suspended. Lucky for the business owner, however, he was able to resume operations in a few weeks or months after repairs were made. Even better, he had the foresight to purchase business interruption insurance, which is intended to place the business owner in the position he would have occupied if the catastrophe had not occurred. ${ }^{6}$

Yet, when the business owner submits a business interruption claim to the insurer, the insurer denies coverage for the claim or offers a paltry sum and advises the business owner that there would have been little or no demand for the business's services or products during the time period its operations were being restored because the area near the business was wiped out by the disaster. Thus, the insurer tells the business owner that the business did not actually suffer a business interruption loss because very few customers or clients would have patronized the business following the disaster even if the business had not been impacted. At best, the insurer tells the owner, what little business he might have had would not have covered the business's fixed costs such as rent and payroll. ${ }^{7}$ Consequently, the insurance policy purchased to cover business interruption losses provides little or no recovery because the business's projected earnings during the period of interruption would not have exceeded its continuing fixed costs. ${ }^{8}$

4. John Grossman, A Business Ponders Whether Its Location is Perfect, or a Disaster, N.Y. TIMES, Dec. 8, 2011, at B6.

5. Id.

6. Miller \& Jean, supra note 2, at 25 ("Business interruption insurance, at its core, is intended to place the insured in the position it would have been in had it not suffered a loss."); Jon C. Rice, Business Interruption Coverage in the Wake of Katrina: Measuring the Insured's Loss in a Volatile Economy, 41 TORT TRIAL \& INS. PRAC. L.J. 857, 857 (2006) ("The purpose of business interruption coverage is to place the insured in the position it would have occupied had no interruption occurred.").

7. See, e.g., Cont'l Ins. Co. v. DNE Corp., 834 S.W.2d 930, 933 (Tenn. 1992).

8. Id. 
Unfortunately, this is not a fictional scenario. It is all too real and it is regularly experienced by many business owners throughout America. There are countless business owners in New Jersey and New York that are currently going through such an experience right now in the wake of Hurricane Sandy.

Insurers take such a position due to the nebulous wording of the loss valuation provisions buried in lengthy, complex, standard form business interruption insurance policies that insurers draft and then sell on a take-it-or-leave-it basis. ${ }^{9}$ The loss valuation language often is worded as follows:

In determining the amount of gross earnings covered hereunder for the purposes of ascertaining the amount of loss sustained, due consideration shall be given to the experience of the business before the date of the damage or destruction and to the probable experience thereafter had no loss occurred. ${ }^{10}$

9. Wagner v. Yates, 912 N.E.2d 805, 811 (Ind. 2009) (“[T]he insurer drafts the policy and foists its terms upon the customer."); 401 Fourth Street, Inc. v. Investors Ins. Grp., 879 A.2d 166, 171 (Pa. 2005) ("[T]he insurer drafts the policy, and controls coverage."). See also 1 JEFFREY W. STEMPEL, LAW OF INSURANCE CONTRACT DisPUTES $\$ 4.06$ (b), at 4-37 (2d ed. Supp. 2005) ("In a sense, the typical insurance contract is one of 'super-adhesion' in that the contract is completely standardized and not even reviewed prior to contract formation."); Kenneth S. Abraham, A Theory of Insurance Policy Interpretation, 95 Мich. L. REV. 531, 534 (1996); Michelle Boardman, Insuring Understanding: The Tested Language Defense, 95 Iowa L. REV. 1075, 1091 (2010) (describing the "hyperstandardization" of insurance policies); James M. Fischer, Why Are Insurance Contracts Subject to Special Rules of Interpretation?: Text Versus Context, 24 ARIZ. ST. L.J. 995, 996 (1992) ("The only part of the standard policy that is generally customized to the consumer-insured is the Declarations Sheet.... [T] here is little, if any, freedom to negotiate the standardized language of the insurance contract that determines the scope of coverage."); Jonathan R. Macey \& Geoffrey P. Miller, The McCarran-Ferguson Act of 1945: Reconceiving the Federal Role in Insurance Regulation, 68 N.Y.U. L. REV. 13, 18 (1993); Susan Randall, Freedom of Contract in Insurance, 14 CoNN. INS. L.J. 107, 125 (2007) (“[I]n some lines of insurance, all insurance companies provide identical coverage on the same take-it-or-leave-it basis."); Daniel Schwarcz, Reevaluating Standardized Insurance Policies, 78 U. CHI. L. REV. 1263, 1266-67, 1276 (2011) (citing sources that discuss the standardization of insurance policies and then arguing homeowners insurance policies are not as standardized as other lines of insurance); Kent D. Syverud, The Duty to Settle, 76 VA. L. REV. 1113, 1153 (1990) (“[P]roperty owner’s liability insurance contracts are standardized across insurers in a form few insureds have the power or experience to bargain around.").

10. Finger Furniture Co. v. Commonwealth Ins. Co., 404 F.3d 312, 314 (5th Cir. 2005) (emphasis added). 
Insurers rely upon the above italicized language when they attempt to support the argument that business interruption losses are negligible or non-existent in situations where the area surrounding a business has been destroyed by a catastrophe such that the demand for the impacted business's services or products has been greatly reduced or eliminated. ${ }^{11}$ Other times, if the catastrophe results in increased demand for the policyholder's services or products, then the insurers argue only the pre-catastrophe sales and expenses of the policyholder should be used to value the loss. ${ }^{12}$

Some courts have accepted the argument that the economic conditions post-catastrophe should be considered when valuing business interruption losses. ${ }^{13}$ Other courts have not. ${ }^{14}$ Courts also have disagreed regarding which elements of a business interruption loss are recoverable. ${ }^{15}$ In addition, some courts have required the policyholder to prove the amount of any business interruption loss to a "reasonable degree of certainty" even though such calculations are, by necessity, only projections regarding what the policyholder would have earned in the hypothetical world in which the catastrophe did not occur. ${ }^{16}$ All of these inconsistencies and problems reflected in the courts' decisions flow from the nebulous valuation language that is contained in business interruption policies.

In this Article, the author contends that if the existing policy language continues to be used, then the ambiguities in it should be construed in favor of policyholders and against insurers, which should lead to inconsistent results that consistently favor policyholders. A better approach, however, would be to redraft the loss valuation provisions. Instead of using the vague loss valuation language that currently exists, business interruption policies should include a stated daily loss value for business interruption claims, which already is developed and used during the underwriting

\footnotetext{
11. See infra Part II.

12. See infra Part II.B.

13. $I d$.

14. See infra Part II.A.

15. See infra Part II.C.

16. See infra notes $120,121$.
} 
process. ${ }^{17}$ The stated daily loss value is the amount, at the time the policy is placed, that the policyholder is projected to lose on a daily basis if its operations are interrupted. ${ }^{18}$ It is a number that is derived from the policyholder's current expense and revenue data and is revised annually during the policy renewal process so it always is up to date. Insurers already use the number during the underwriting process to assess the risk and establish the amount of the premium. ${ }^{19}$ Alternatively, only the policyholder's earnings and cost data for the three years prior to the business interruption could be used to value business interruption losses. Using a three-year time period should account for the seasonal or cyclical nature of some businesses' revenue streams.

The advantages of using either proposal are that they establish a fixed number that is agreed to by the parties at the time the policy is placed regarding the amount a policyholder will be paid if its operations are interrupted. Both proposals would eliminate debates between the parties regarding the state of the economy, the trends in the policyholder's industry, and the impact the catastrophe had on the local business climate. Such debates are at the center of the current litigation regarding business interruption losses and they result in an enormous waste of the parties' and courts' resources as cases unnecessarily wind their way through the legal system and are ultimately presented to juries because the outcomes of the cases are unpredictable under the existing policy language. ${ }^{20}$ Thus, if adopted, either proposal would provide consistent, predictable results and the efficient resolution of claims without the necessity of litigation in most instances.

This Article addresses these issues in four parts. Part One discusses the origins and purpose of business interruption insurance, which is to ensure that the policyholder's revenue stream continues during the period of interruption, as well as the policy language

\footnotetext{
17. See infra note 216 .

18. Stan Johnson \& Kevin O'Toole, Common Business Interruption Measurement Disputes, 19 JOHN LINER REV. 59, 65 (2005).

19. See infra note 216.

20. See infra Part II.
} 
relevant to the valuation of business interruption losses. Part Two discusses the conflicting court opinions regarding the valuation of business interruption losses. Part Three discusses the rules of policy interpretation that are relevant to interpreting and applying the existing policy language. Part Three also explores the idea that, in light of the fact that policies are non-negotiated contracts of adhesion sold on a take-it-or-leave-it basis, the loss valuation language can be viewed as a defective product if the policy fails to perform as reasonably expected by the policyholder (i.e., the policyholder does not receive payment from the insurer for the full amount of the policyholder's business interruption loss). Part Four discusses the problems with the existing policy language and current approaches to valuing business interruption losses. Part Four also discusses public policy considerations, such as the importance of ensuring that policyholders receive the benefit of the bargain for the premiums they paid, and ensuring that the socially important purpose of insurance - transferring the risk of losses from individuals and businesses to insurers-is not frustrated by insurers' interest in maximizing their profits by minimizing the amounts they pay for catastrophic losses by relying upon vaguely-worded loss valuation provisions they themselves drafted and buried in policies that often exceed fifty pages of single-spaced terms, conditions and exclusions. The Article concludes with the author's proposal that instead of using the existing policy language, the policies either should contain a daily loss value or specify that only the policyholders' prior three years of revenue and cost data will be used to calculate business interruption losses. If insurers will not voluntarily redraft the loss valuation language to clarify how business interruption losses will be calculated, then the author proposes that: (1) courts should construe the nebulous loss valuation language strictly against insurers as required under the existing rules of policy interpretation, and (2) legislatures should enact legislation that dictates how business interruption losses will be valued in accordance with one of the proposals made in this Article. 


\section{Relevant Policy Language}

\section{A. The Origins of Business Interruption Insurance}

The genealogy of business interruption insurance begins over two hundred years ago and has its roots in insurance that was issued to protect property owners' rental income. ${ }^{21}$ Because property insurance historically did not protect against lost rent, separate coverage had to be purchased. ${ }^{22}$ Originally, such insurance was referred to as "use and occupancy" insurance. ${ }^{23}$ In the 1930s, the name evolved to business interruption insurance and in the 1980s the Insurance Services Office (ISO) coined the term "business income insurance" when it issued a new policy form for business interruption insurance. $^{24}$

As many courts and commentators have stated, the purpose of business interruption insurance is to return the policyholder to the position it would have occupied if the disaster had not occurred:

The purpose of business interruption insurance is to protect the insured against losses that occur when its operations are unexpectedly interrupted, and to place it in the position it would have occupied if the interruption had not occurred. ${ }^{25}$

The modern forms of business interruption insurance, which cover net profits plus continuing expenses such as payroll and taxes, were introduced in the mid-1920s. ${ }^{26}$ There currently are two common business interruption policy forms: 1) Gross Earnings and 2) Business Income. $^{27}$ Gross Earnings forms calculate business

\footnotetext{
21. TORPEY, LENTZ \& MELTON, supra note 1 , at 1 .

22. Id.

23. Id. at 5. Use and occupancy insurance typically had a loss per day value set forth in the policy. $I d$. at 6 . Consequently, there was no need for, and little room to, debate what the amount of lost income was in the event of a business interruption. Id.

24. Id. at 5 .

25. Cont'l Ins. Co. v. DNE Corp., 834 S.W.2d 930, 934 (Tenn. 1992) (citing Nw. States Portland Cement Co. v. Hartford Fire Ins. Co., 360 F.2d 531 (8th Cir. 1966)). See also Miller \& Jean, supra note 2 , at 25; Rice, supra note 6, at 857.

26. TORPEY, LENTZ \& MELTON, supra note 1 , at 8.

27. Id. at 9,14 (describing the gross earnings form and the business income form). See also David A.
} 
interruption losses from the top down, which means the business interruption loss is the total amount the policyholder would have earned if not for the interruption of its operations less the costs or expenses the policyholder did not incur due to the interruption in its business (i.e., the variable costs it saved because its operations were suspended). ${ }^{28}$ Business Income forms calculate business interruption losses from the bottom up, which means the business interruption loss is the net income the policyholder would have earned if not for the interruption plus the policyholder's continuing fixed expenses such as payroll and taxes. ${ }^{29}$ In theory, the amount of a business interruption loss should be the same under the two policy forms. ${ }^{30}$

\section{B. The Policy Language Regarding the Valuation of Business Interruption Losses}

Although there are many minor variations in the wording used in business interruption policies because insurers often have their own policy form that they prefer to use, all such forms are drafted by insurers. ${ }^{31}$ The policies are contracts of adhesion and sold on a takeit-or-leave-it basis. ${ }^{32}$ One common version of the insuring agreement language found in Gross Earnings policy forms provides:

[The insurer] shall be liable for the ACTUAL LOSS SUSTAINED by insured resulting directly from such interruption of business, but not exceeding the reduction in gross earnings less charges and expenses which do not necessarily

\footnotetext{
Borghesi, Business Interruption Insurance: A Business Perspective, 17 Nova L. REV. 1147, 1150 (1993) (discussing the types of business interruption policy forms); Lori R. Keeton, Business Interruption Coverage in the Wake of the Gulf Coast Oil Spill: The Devil Is in the Details, ASPATORE (Mar. 2011), 2011 WL 971800, at *6.

28. TORPEY, LENTZ \& MELTON, supra note 1, at 10-12; Borghesi, supra note 27, at 1150; Keeton, supra note 27 , at $* 6$.

29. TORPEY, LENTZ \& MELTON, supra note 1, at 15; Borghesi, supra note 27, at 1150; Keeton, supra note 27 , at $* 6$.

30. Borghesi, supra note 27, at 1150.

31. See supra note 9.

32. Id.
} 
continue during the interruption $\ldots{ }^{33}$

In short, the policyholder is entitled to recover its lost gross earnings less saved variable expenses.

A common version of the insuring agreement language used in Business Income policy forms is worded as follows:

[The insurer] will pay an insured during its period of suspended business operation the "(i) Net Income (Net Profit or Loss before income taxes) that would have been earned or incurred if no physical loss or damage had occurred ...; and (ii) Continuing normal operating expenses incurred, including payroll[.]"34

In short, the policyholder is entitled to recover its net profits plus fixed continuing expenses.

The loss valuation provisions are commonly worded as follows:

In determining the amount of gross earnings covered hereunder for the purposes of ascertaining the amount of loss sustained, due consideration shall be given to the experience of the business before the date of the damage or destruction and to the probable experience thereafter had no loss occurred. ${ }^{35}$

33. Finger Furniture Co. v. Commonwealth Ins. Co., 404 F.3d 312, 314 (5th Cir. 2005). For similar insuring agreement language, see also Catlin Syndicate Ltd. v. Imperial Palace of Miss., Inc., 600 F.3d 511, 514 (5th Cir. 2010); Prudential LMI Commercial Ins. Co. v. Colleton Enters., Inc., No. 91-1757, 1992 WL 252507, at *1 (4th Cir. Oct. 5, 1992); Consol. Cos. v. Lexington Ins. Co., No. 06-4700, 2009 U.S. Dist. LEXIS 8542, at*16-17 (E.D. La. Jan. 23, 2009); Berk-Cohen Assocs. v. Landmark Am. Ins. Co., No. 07-9205, 2009 WL 2777163, at *3 (E.D. La. Aug. 27, 2009); B.F. Carvin Constr. Co. v. CNA Ins. Co., No. 06-7155, 2008 WL 5784516, at*1 (E.D. La. July 14, 2008); Levitz Furniture Corp. v. Hous. Cas. Co., No. 96-1790, 1997 WL 218256, at*3 (E.D. La. Apr. 28, 1997); Am. Auto. Ins. Co. v. Fisherman's Paradise Boats, Inc., No. 93-2349CIVGRAHAM, 1994 WL 1720238, at*3 (S.D. Fla. Oct. 3, 1994).

34. Amerigraphics, Inc. v. Mercury Cas. Co., 107 Cal. Rptr. 3d 307, 312 (Cal. Ct. App. 2010) (quoting policy language). For similar insuring agreement language, see also Catlin Syndicate Ltd., 600 F.3d at 514; Finger Furniture, 404 F.3d at 314; Prudential LMI Commercial Ins. Co., 1992 WL 252507, at *1; Consol. Cos., 2009 U.S. Dist. LEXIS 8542, at *16-17; Berk-Cohen, 2009 WL 2777163, at *4; B.F. Carvin Constr. Co., 2008 WL 5784516, at *1; Levitz Furniture Corp., 1997 WL 218256, at *3; Am. Auto. Ins. Co., 1994 WL 1720238, at*3.

35. Finger Furniture, 404 F.3d at 314 (emphasis added). See also cases cited infra notes 44, 67. 
Notably, the term "gross earnings" is not defined in the policies. ${ }^{36}$ Also, this language clearly contemplates doing a projection regarding the business's "probable experience" if the loss had not occurred. ${ }^{37}$

Another version of the valuation language that also is often used provides:

We'll cover your actual loss of earnings and extra expenses incurred because of necessary or potential interruption of business .... In figuring earnings, we'll weigh the performance of your business before the loss and what its performance probably would have been afterwards had no loss occurred. ${ }^{38}$

Again, the language contemplates that an analysis will be conducted regarding what the policyholder's hypothetical "performance probably would have been" if no loss had occurred. ${ }^{39}$

\section{COURTS' InTERPRETATION AND APPliCATION OF THE Policy LANGUAGE REGARDING THE VALUATION OF BUSINESS INTERRUPTION LOSSES}

Due to the broad language used in the loss valuation provisions of business interruption insurance, the use of many undefined terms, and the fact that a formula for valuing business interruption losses is not actually contained in such provisions, it should come as no

\footnotetext{
36. Finger Furniture, 404 F.3d at 314.

37. Id.

38. Cohen Furniture Co. v. St. Paul Ins. Co. of Ill., 573 N.E.2d 851, 855 (Ill. App. Ct. 1991) (emphasis added). See also cases cited infra notes 44, 67.

39. Notably, some policies contain language that specifically precludes the consideration of policyholder-favorable economic conditions post-loss when valuing the business interruption loss. Such policies commonly are worded as follows:

The amount of Business Income loss will be determined based on:

(1) The Net Income of the business before the direct physical loss or damage occurred;

(2) The likely Net Income of the business if no physical loss or damage occurred, but not including any likely increase in Net Income attributable to an increase in the volume of business as a result of favorable business conditions caused by the impact of the Covered Cause of loss on customers or on other businesses ....

Legier \& Co. v. Travelers Indem. Co. of Conn., No. 09-6674, 2010 WL 1731202, at *2 (E.D. La. Apr. 28, 2010). See also Berk-Cohen Assocs, 2009 WL 2777163, at *3; Rimkus Consulting Grp., Inc. v. Hartford Cas. Ins. Co., 552 F. Supp. 2d 637, 640 (S.D. Tex. 2007).
} 
surprise that the courts' decisions regarding how business interruption losses should be valued are varied and inconsistent. Some courts interpret the valuation language to require that the loss calculation be based upon only the historical financial data of the policyholder. ${ }^{40}$ Other courts also allow the local post-catastrophe economic conditions to be considered. ${ }^{41}$ In addition, when applying the standard valuation language to claims that arise under similar factual scenarios, the courts have reached patently inconsistent conclusions regarding which of the policyholder's ongoing expenses are recoverable. ${ }^{42}$ One consistency, however, does appear in the decisions - the courts are confused regarding the evidentiary standard that should apply when a policyholder is attempting to prove the amount of its business interruption loss. ${ }^{43}$

\section{A. Courts That Have Interpreted the Loss Valuation Language to Allow for Consideration of Only Historical Financial Data}

One school of thought, which most notably has been endorsed by the Fifth Circuit, only considers the historical financial data of the policyholder when calculating business interruption losses. ${ }^{44}$ In Finger Furniture, ${ }^{45}$ the policyholder owned seven furniture stores in Houston, Texas. ${ }^{46}$ Tropical Storm Allison hit the Houston area and

\footnotetext{
40. See infra Part II.A.

41. See infra Part II.B.

42. See infra Part II.C.

43. See infra Part II.D.

44. Catlin Syndicate Ltd. v. Imperial Palace of Miss., Inc., 600 F.3d 511, 514 (5th Cir. 2010) (following Finger Furniture and only allowing the use of historical financial information when determining a business interruption loss); Finger Furniture Co. v. Commonwealth Ins. Co., 404 F.3d 312, 314 (5th Cir. 2005) (allowing only historical financial information to be used to predict policyholder's "probable experience" during period of interruption); Prudential LMI Commercial Ins. Co. v. Colleton Enters., Inc., No. 91-1757, 1992 WL 252507, at *4 (4th Cir. Oct. 5, 1992) (disallowing the policyholder to calculate its business interruption loss based upon favorable post-loss economic environment created by a hurricane); Am. Auto. Ins. Co. v. Fisherman's Paradise Boats, Inc., No. 932349CIVGRAHAM, 1994 WL 1720238, at *4 (S.D. Fla. Oct. 3, 1994) (citing Colleton, 1992 WL 252507 , at $* 2$ ) (finding increased demand for policyholder's products due to favorable economic environment created by a hurricane cannot be considered when valuing the policyholder's business interruption loss).

45. Finger Furniture Co. v. Commonwealth Ins. Co., 404 F.3d 312 (5th Cir. 2005)

46. Id. at 313 .
} 
caused severe flooding. ${ }^{47}$ As a result, the policyholder could not open its stores for a period of time. ${ }^{48}$ Consequently, the policyholder submitted a business interruption loss claim to its insurer. ${ }^{49}$ The parties could not agree on the amount of the business interruption loss, litigation ensued, and ultimately the parties filed cross motions for summary judgment. ${ }^{50}$ The policy at issue contained the following language:

In determining the amount of gross earnings covered hereunder for the purposes of ascertaining the amount of loss sustained, due consideration shall be given to the experience of the business before the date of the damage or destruction and to the probable experience thereafter had no loss occurred. ${ }^{51}$

Relying upon the "probable experience thereafter" policy language, the insurer argued the policyholder did not actually suffer a business interruption loss because demand for furniture in the area was high after the tropical storm passed and the policyholder was able to quickly make up the sales allegedly lost during the period of interruption. ${ }^{52}$ The Fifth Circuit rejected the insurer's argument and held that only the policyholder's historical sales figures could be used to calculate the loss. ${ }^{53}$ In explaining its decision, the court stated:

The policy language indicates that a business-interruption loss will be based on historical sales figures. Specifically, the policy states that "due consideration shall be given to the experience of the business before the date of the damage or destruction and to the probable experience thereafter had no loss occurred." Historical sales figures reflect a business's experience before the date of the damage or destruction and predict a company's

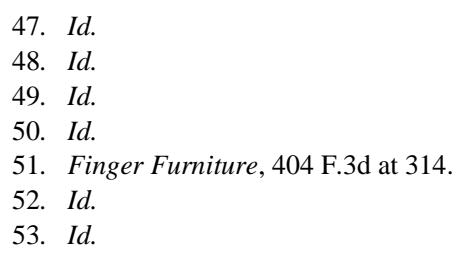


probable experience had the loss not occurred. The strongest and most reliable evidence of what a business would have done had the catastrophe not occurred is what it had been doing in the period just before the interruption. ${ }^{54}$

The court further explained that, contrary to the insurer's position, the policy did not expressly state that post-catastrophe sales should be considered when determining what the sales would have been had the storm not occurred:

[T]he business-loss provision says nothing about taking into account actual post-damage sales to determine what the insured would have experienced had the storm not occurred. The contract language does not suggest that the insurer can look prospectively to what occurred after the loss to determine whether its insured incurred a business-interruption loss. Instead, the policy requires due consideration of the business's experience before the date of the loss and the business's probable experience had the loss not occurred. [The policyholder's] historical sales figures reflect that consideration. ${ }^{55}$

Thus, in this instance, the court's decision not to consider the postcatastrophe economic conditions favored the policyholder.

Five years later, the Fifth Circuit reaffirmed its commitment to considering only the policyholder's historical financial information when valuing business interruption losses in Catlin Syndicated Ltd. $v$. Imperial Palace of Mississippi, Inc. ${ }^{56}$ In Catlin, the policyholder operated a casino that was damaged by Hurricane Katrina. ${ }^{57}$ The casino was shut down for several months, but when it reopened "its revenues were...greater than before the hurricane[,]" because "many [of the] nearby casinos remained closed." 58 In valuing the

54. Id.

55. Id.

56. See Catlin Syndicate Ltd. v. Imperial Palace of Miss., Inc., 600 F.3d 511, 516 (5th Cir. 2010).

57. Id. at 512

58. Id. 
business interruption loss for the casino, there was a $\$ 100$ million discrepancy between the policyholder's calculation, which was based in part upon the business's post-hurricane experience, and the insurer's calculation, which was based upon only the business's prehurricane experience. ${ }^{59}$

The valuation language in the policy at issue was worded as follows: "In determining the amount of the Time Element ${ }^{60}$ loss as insured against by this policy, due consideration shall be given to experience of the business before the loss and the probable experience thereafter had no loss occurred." 61 With each party arguing that the court should adopt their interpretation of the policy language, the parties filed cross-motions for summary judgment. ${ }^{62}$

The court, relying upon Finger Furniture, held only the historical sales information could be used to calculate the loss. ${ }^{63}$ The court explained its reasoning as follows:

Finger Furniture tells us "that a business-interruption loss will be based on historical sales figures," and that we should not "look prospectively to what occurred after the loss." Thus, in the business-interruption provision at hand, only historical sales figures should be considered when determining loss, and sales figures after reopening should not be taken into account. ${ }^{64}$

Thus, unlike in Finger Furniture, the court's decision not to allow post-catastrophe economic conditions to be considered favored the insurer.

In both cases, however, the Fifth Circuit interpreted the "probable experience thereafter" phrase to mean the probable experience the

\footnotetext{
59. Id. at 512-13.

60. Business interruption insurance is a type of insurance that sometimes is referred to as "time element" insurance, because the period of time a business is interrupted is one of the principal factors involved in valuing the loss. Bernard P. Bell, General Purpose of Time Element Insurance, in 5 NEW APPLEMAN ON INSURANCE LAW LIBRARY EDITION § 46.01 (2013).

61. Catlin, 600 F.3d at 513.

62. Id.

63. Id. at 516

64. Id. (citing Finger Furniture Co. v. Commonwealth Ins. Co., 404 F.3d 312, 314 (5th Cir. 2005)).
} 
policyholder would have had post-catastrophe, assuming the policyholder's post-catastrophe experience would be identical to its pre-catastrophe experience. ${ }^{65}$ Several courts in other jurisdictions have reached similar conclusions. ${ }^{66}$

\section{B. Courts That Have Interpreted the Loss Valuation Language to Allow for the Consideration of Local Economic Conditions Post- Catastrophe}

At the other end of the spectrum, several courts have held that local post-catastrophe economic conditions should be considered when business interruption losses are valued. ${ }^{67}$ Although there are not enough decisions, particularly appellate decisions, on the issue to proclaim that any particular school of thought is the majority position, more courts, especially in Louisiana, have endorsed this approach than the Fifth Circuit's approach. ${ }^{68}$

A leading case, and arguably the controlling authority on the issue under Louisiana law, that used this approach is Sher v. Lafayette Insurance Co. ${ }^{69}$ In Sher, the policyholder owned an apartment building in New Orleans that was damaged by Hurricane Katrina. ${ }^{70}$ Although there were multiple issues in dispute between the policyholder and the insurer, the primary dispute with respect to the

65. Id. at 514; Finger Furniture, 404 F.3d at 314.

66. See supra note 44.

67. Fireman's Fund Ins. Co. v. Holland Am. Line-Westours, Inc., 25 Fed. App'x 602, 603 (9th Cir. 2002) (allowing insurer to use "make up" sales of the policyholder post-loss to reduce the amount owed); Consol. Cos. v. Lexington Ins. Co., No. 06-4700, 2009 U.S. Dist. LEXIS 8542, at*20 (E.D. La. Jan. 23, 2009) (allowing jury to base award to policyholder upon increased demand created by hurricane); Berk-Cohen Assocs. v. Landmark Am. Ins. Co., No. 07-9205, 2009 WL 2777163, at *5 (E.D. La. Aug. 27, 2009) (allowing policyholder to use higher post-loss rent values when calculating its business interruption loss); B.F. Carvin Constr. Co. v. CNA Ins. Co., No. 06-7155, 2008 WL 5784516, *3 (E.D. La. July 14, 2008) (finding policyholder did not suffer a business interruption loss because favorable economic conditions post-loss caused an increase in sales); Levitz Furniture Corp. v. Hous. Cas. Co., No. 96-1790, 1997 WL 218256, *3 (E.D. La. Apr. 28, 1997) (allowing policyholder to calculate its business interruption loss based upon higher demand for its product caused by flooding); Sher v. Lafayette Ins. Co., 973 So. 2d 39, 62 (La. Ct. App. 2007), aff'd in part, rev'd in part, 988 So. 2d 186, 205 (La. 2008) (allowing policyholder to use higher post-loss rent values in calculating its business interruption loss).

68. See cases cited supra note 67.

69. Sher, 973 So. $2 \mathrm{~d}$ at 47 .

70. Id. 
business interruption claim related to whether pre-Katrina or postKatrina rent rates should be used to value the business interruption loss. $^{71}$

The policy language at issue provided: "We will pay for the actual loss of Business Income you sustain due to the necessary suspension of your 'operations' during the "period of restoration.",72 The policyholder argued that, under this language, post-Katrina rent rates should be used because housing had become scarce due to the extensive damage in the area, while the insurer argued pre-Katrina rates should be used. ${ }^{73}$

The case was tried to a jury and the jury found in favor of the policyholder. ${ }^{74}$ On appeal, the intermediate appellate court, with little explanation, held that the policyholder could recover the higher postKatrina rent rates, stating "the Policy covers [the policyholder's] 'actual loss' of business income." 75 In making this statement, the court implicitly interpreted the phrase "actual loss" to mean the amount the policyholder would have earned if the policyholder's business had not been damaged by the hurricane but the area around the policyholder's business had been damaged. ${ }^{76}$ Because the jury agreed with the policyholder's loss calculation using the post-Katrina rent rates, the court affirmed the jury verdict. ${ }^{77}$ On appeal, the Supreme Court of Louisiana reversed the lower courts' rulings on some issues, but not the holdings regarding the valuation of the business interruption loss. ${ }^{78}$ Thus, the Louisiana state courts implicitly rejected the Fifth Circuit's approach by allowing the consideration of post-catastrophe economic conditions in valuing the loss. $^{79}$

71. Id. at 57.

72. Id.

73. $I d$.

74. Id. at 49 .

75. Sher, 973 So. $2 d$ at 57.

76. Id.

77. Id.

78. Sher v. Lafayette Ins. Co., 988 So. 2d 186, 205 (La. 2008).

79. See cases cited supra note 67. 
Another Louisiana decision in which the court held the policyholder's business interruption loss should be calculated based upon post-catastrophe economic conditions is Berk-Cohen Associates, LLC v. Landmark American Insurance Co. ${ }^{80}$ In BerkCohen, the policyholder was the owner of an apartment complex that was damaged by "a series of unfortunate events." struck the apartment complex. ${ }^{82}$ Two weeks later, before any repairs had been made, Hurricane Katrina "decimated" New Orleans and further damaged the apartment complex. ${ }^{83}$ Then, while the postKatrina repairs were underway, a fire broke out at the apartment complex. ${ }^{84}$ Finally, while repairs were again underway, a vehicle struck a transformer, which caused a power outage ${ }^{85}$ From beginning to end, the repair work took almost two years to complete. ${ }^{86}$

When valuing the business interruption loss, the parties could not agree on the amount of the loss because, among other reasons, the policyholder contended the housing shortage caused by Hurricane Katrina increased the rental value of the apartments by $40 \% .{ }^{87}$ The insurer, on the other hand, valued the loss based upon pre-Katrina rates. ${ }^{88}$ The valuation language in the policy provided:

The amount of Business Income loss will be determined based on: (1) The Net Income of the business before the direct physical loss or damage occurred; (2) The likely Net Income of the business if no physical loss or damage had occurred, but not including any Net Income that would likely have been earned as a result of an increase in the volume of business due to favorable business conditions caused by the impact of the Covered Cause

\footnotetext{
80. Berk-Cohen Assocs. v. Landmark Am. Ins. Co., No. 07-9205, 2009 WL 2777163 (E.D. La. Aug. 27, 2009).

81. Id. at $* 1$

82. $I d$.

83. $I d$.

84. Id.

85. $I d$.

86. Berk-Cohen, 2009 WL 2777163, at *1.

87. Id. at $* 3$.

88. Id.
} 
of Loss on customers or on other businesses[.] $]^{89}$ ...

In determining the amount of gross earnings covered hereunder for the purposes of ascertaining the amount of loss sustained, due consideration shall be given to the experience of the business before the date of the damage or destruction and to the probable experience thereafter had no loss occurred. ${ }^{90}$

The court held the policyholder's recovery should be based upon the post-Katrina rental rates. ${ }^{91}$ In reaching its holding, the court distinguished Finger Furniture, ${ }^{92}$ the ostensibly controlling Fifth Circuit authority, by accepting the policyholder's argument that: (1) the policy language at issue was different than the language in Finger Furniture, and (2) the policy language quoted above that provides the loss will not be valued based upon favorable post-catastrophe business conditions created by a "covered cause of loss" did not apply because flooding, an excluded cause of loss, as opposed to a covered cause of loss, created the favorable business conditions ${ }^{93}$ Thus, the court allowed the policyholder to successfully circumvent the policy language which, on its face, appeared to preclude consideration of the favorable post-catastrophe business conditions in the area.

Although the reasoning has varied somewhat from decision to decision, several other courts also have reached the conclusion that post-catastrophe economic conditions should be considered when valuing business interruption losses. ${ }^{94}$

\footnotetext{
89. $I d$.

90. Id. at $* 4$ (citing Finger Furniture Co. v. Commonwealth Ins. Co., 404 F.3d 312, 314 (5th Cir. 2005)).

91. $I d$. at $* 5$.

92. Finger Furniture Co. v. Commonwealth Ins. Co., 404 F.3d 312, 314 (5th Cir. 2005).

93. Berk-Cohen, 2009 WL 2777163, at*5.

94. See supra note 67.
} 


\section{Courts' Inconsistent Holdings Regarding the Application of the Loss Valuation Language}

In addition to disagreeing on whether post-catastrophe economic
conditions should be considered when analyzing business
interruption losses, the courts also have reached inconsistent
conclusions regarding when, and whether, certain expenses are
recoverable under the standard valuation language contained in
business interruption policies. ${ }^{95}$ This inconsistency is highlighted by

95. Compare Nat'l Union Fire Ins. Co. of Pittsburgh v. Anderson-Prichard Oil Corp., 141 F.2d 443, 446 (10th Cir. 1944) (affirming lower court's ruling in favor of policyholder and finding "no prescribed formula for the determination of the actual loss of net profits and business expenses covered by the policy"), Legier \& Co. v. Travelers Indem. Co. of Conn., No. 096674, 2010 WL 1731202, at*1, *3 (E.D. La. Apr. 28, 2010) (allowing policyholder to recover net income plus continuing fixed costs but requiring the policyholder to credit the insurer with revenues received during the period of interruption and noting "the policy does not prescribe an explicit formula to calculate loss of business income"), Amerigraphics, Inc. v. Mercury Cas. Co., 107 Cal. Rptr. 3d 307, 320 (Cal. Ct. App. 2010) (allowing policyholder to recover its continuing fixed costs even if it would have suffered a loss during the period of interruption in the absence of a flood), and Gates v. State Auto. Mut. Ins. Co., 196 S.W.3d 761, 76667 (Tenn. Ct. App. 2005) (allowing policyholder to recover revenues that would have been received after the period of interruption so long as they were "earned" during the period of interruption), with Polymer Plastics Corp. v. Hartford Cas. Ins. Co., 389 F. App'x 703, 705 (9th Cir. 2010) (holding that earnings made during period of interruption should be used to reduce the amount of the business interruption loss), Associated Photographers, Inc. v. Aetna Cas. \& Sur. Co., 677 F.2d 1251, 1256 (8th Cir. 1982) (holding the insurer can deduct the amount of saved variable expenses when calculating the amount of a business interruption loss), Nw. States Portland Cement Co. v. Hartford Fire Ins. Co., 360 F.2d 531, 534 (8th Cir. 1966) (finding where inventory was sold to prevent loss of earnings during period of business interruption, only the extra expenses incurred to replace the inventory sold was recoverable), HTI Holdings, Inc. v. Hartford Cas. Ins. Co., No. 10-6021-AA, 2011 WL 6205903, at *7 (D. Or. Dec. 8, 2011) (holding that projected negative net income during period of interruption can be used by insurer to offset continuing fixed costs when calculating a business interruption loss amount), Admiral Indem. Co. v. Bouley Int'l Holding, LLC, No. 02 Civ. 9696(HB), 2003 WL 22682273, at *2 (S.D.N.Y. Nov. 13, 2003) (holding amounts paid to policyholder for different use of property during period of interruption should be used to reduce amount of the business interruption loss), Stone Container Corp. v. Arkwright Mut. Ins. Co., No. 93C6626, 1997 U.S. Dist. LEXIS 3978, at *8-9 (N.D. Ill. Mar. 25, 1997) (finding that policyholder did not suffer a business interruption loss because it was able to satisfy orders by selling inventory which the policyholder did not replenish after the period of interruption), Baxter Int'l, Inc. v. Am. Guarantee \& Liab. Ins. Co., 861 N.E.2d 263, 271 (Ill. App. Ct. 2006) (holding insurer can use policyholder's sales during period of interruption to reduce amount of policyholder's loss), Lyon Metal Prods., LLC v. Prot. Mut. Ins. Co., 747 N.E.2d 495, 504 (IIl. App. Ct. 2001) (finding insurer can offset payments made for damaged inventory when calculating the value of the business interruption loss), Cohen Furniture Co. v. St. Paul Ins. Co. of Ill., 573 N.E.2d 851, 857 (Ill. App. Ct. 1991) (holding policyholder cannot recover depreciation for a completely destroyed building because depreciation is not a continuing expense under business interruption insurance in that circumstance), J\&R Elecs. Inc. v. One Beacon Ins. Co., No. 603284/2004, 2005 WL 4257996, at *2 (N.Y. Sup. Ct. Dec. 13, 2005) (holding policyholder cannot recover for damaged merchandise under both property damage provisions of policy and business interruption provisions of policy), Cont'l Ins. Co. v. DNE Corp., 834 S.W.2d 930, 934 (Tenn. 1992) (finding insurer must add projected net income 
the courts' treatment of the issue of whether a policyholder can recover its continuing fixed expenses such as rent and payroll in situations where the policyholder likely would have lost money during the period of interruption, even if its operations had not been interrupted. $^{96}$

Consider again the insuring agreement provisions commonly found in standard business interruption policies:

[The insurer] will pay an insured during its period of suspended business operation the "(i) Net Income (Net Profit or Loss before income taxes) that would have been earned or incurred if no physical loss or damage had occurred ...; and (ii) Continuing normal operating expenses incurred, including payroll[..",97

Thus, a question that arises is whether a policyholder can recover its continuing operating expenses during the period of interruption if it was actually losing money prior to the business interruption and was projected to continue losing money during the period of interruption even if the interruption had not occurred. In other words, does one add together the projected "net income" and "continuing operating expenses" in determining the recoverable loss or are the "continuing operating expenses" recoverable regardless of whether the "net income" figure is positive or negative?

\footnotetext{
and continuing expenses together when calculating a business interruption claim even if the net income number is negative), and Keetch v. Mut. of Enumclaw Ins. Co., 831 P.2d 784, 786 (Wash. Ct. App. 1992) (holding decrease in business activity due to a partial interruption of business, as opposed to a complete interruption of business, is not a reimbursable business interruption loss).

96. Compare Amerigraphics, $107 \mathrm{Cal}$. Rptr. 3d at 318 (allowing insured to recover its continuing fixed costs), with DNE, 834 S.W.2d at 934 (denying insured recovery of business income).

97. Amerigraphics, 107 Cal. Rptr. 3d at 312. See also Catlin Syndicate Ltd. v. Imperial Palace of Miss., Inc., 600 F.3d 511, 514 (5th Cir. 2010); Finger Furniture, 404 F.3d at 314; Prudential LMI Commercial Ins. Co. v. Colleton Enters., Inc., No. 91-1757, 1992 WL 252507, at*1 (4th Cir. Oct. 5, 1992); Berk-Cohen, 2009 WL 2777163, at *4; Consol. Cos. v. Lexington Ins., No. 06-4700, 2009 U.S. Dist. LEXIS 8542, at *16-17 (E.D. La. Jan. 23, 2009); B.F. Carvin Constr. Co. v. CNA Ins. Co., No. 06-4700, 2008 WL 5784516, at *1 (E.D. La. July 14, 2008); Levitz Furniture Corp. v. Hous. Cas. Co., No. 96-1790, 1997 WL 218256, at*3 (E.D. La. Apr. 28, 1997); Am. Auto. Ins. Co. v. Fisherman's Paradise Boats, Inc., No. 93-2349CIVGRAHAM, 1994 WL 1720238, at*3 (S.D. Fla. Oct. 3, 1994).
} 
Two decisions, Amerigraphics, Inc. v. Mercury Casualty Co. ${ }^{98}$ and Continental Insurance Co. v. DNE Corp., ${ }^{99}$ illustrate the courts' inconsistent interpretations of this policy language. In Amerigraphics, the policyholder was a printing and graphics company. ${ }^{100}$ Following the $9 / 11$ terrorist attack, business was poor. ${ }^{101}$ Post-9/11, while business was poor, the company's premises were flooded. ${ }^{102}$ The insurer refused to pay the policyholder anything for its business interruption claim under the theory that the policyholder was losing money at the time of the business interruption and would have continued to lose money even if its operations had not been interrupted. ${ }^{103}$ The policyholder contended it nonetheless was entitled to recover its continuing fixed costs without an offset for the projected negative net income. ${ }^{104}$

The trial court agreed with the policyholder and the intermediate appellate court affirmed, stating:

$[\mathrm{U}]$ nder the plain language of the policy, the business-income provision should be interpreted to mean that [the insurer] will pay an insured for any lost income and will pay an insured its continuing normal business expenses during the period of business suspension. To the extent there is no lost income (i.e., there is only a net loss), the amount paid under subpart (i) would be zero, but the insured would still be paid under subpart (ii) for its operating expenses .... [T] he policy does not use the words "plus," "offset," "subtract," "minus," or the like. It uses the word "and." The plain meaning of "and" is consistent with [the policyholder's] and the trial court's interpretation. ${ }^{105}$

\footnotetext{
98. Amerigraphics, 107 Cal. Rptr. at 307.

99. DNE, 834 S.W.2d at 930.

100. Amerigraphics, 107 Cal. Rptr. at 312.

101. $I d$.

102. Id.

103. Id. at 315 .

104. Id. at 316

105. Id. at $318-19$
} 
Thus, the policyholder was allowed to recover its continuing fixed expenses even though it would have incurred a loss if its business operations had not been interrupted.

The Supreme Court of Tennessee reached the opposite conclusion in $D N E .^{106}$ In $D N E$, the policyholder made transmission and gear products for the automotive industry. ${ }^{107}$ It had been operating at a loss for some time prior to when its operations were interrupted due to a tornado. ${ }^{108}$ As was the case in Amerigraphics, the policyholder contended recovery of its continuing fixed expenses should not be offset by its projected net income loss. ${ }^{109}$ The insurer contended the policyholder should recover nothing because the policyholder's projected net income loss exceeded the continuing fixed expenses. ${ }^{110}$

The trial court ruled in favor of the insurer. ${ }^{111}$ The Supreme Court of Tennessee affirmed, stating:

The purpose of business interruption insurance is to protect the insured against losses that occur when its operations are unexpectedly interrupted, and to place it in the position it would have occupied if the interruption had not occurred.... [T]he interpretation advocated by [the policyholder] (i.e., ignoring "net income" whenever there is a net loss) would put the insured, in all cases when there is a net loss, in a better economic position from having had its business interrupted than it would have occupied had there been no interruption of its business operations ....We therefore conclude that the amount of "business income" under the insurance policy provision involved in this case should be determined by adding the amount of "net income" and the amount of "continuing normal operating expenses." Under this approach, if "net income" is a positive number (which will occur whenever there are net profits), the

106. Cont'l Ins. Co. v. DNE Corp., 834 S.W.2d 930 (Tenn. 1992).

107. Id. at 931 .

108. Id

109. Id. at 932

110. Id.

111. Id. 
amount of "business income" will be the sum of two positive numbers, and the insured will be entitled to recover that amount. If, however, "net income" is a negative number (which will occur whenever there is a net loss), the amount of "business income" will be the amount of "continuing normal operating expenses" reduced by the amount of the net loss. ${ }^{112}$

Thus, the court would not allow the policyholder to recover continuing fixed expenses if they exceeded the amount of the projected net income loss.

The court's decision in DNE raises the specter that, in a jurisdiction such as Tennessee, an insurer may be engaging in a form of fraud by selling business interruption insurance to a policyholder whose business is operating at a loss. ${ }^{113}$ If the policy does not cover the continuing operating expenses of a business that is losing money when its operations are interrupted by a covered loss, then what value does the policyholder receive in exchange for the premium it pays for business interruption coverage?

Aside from raising that intriguing question, the answer to which is beyond the scope of this Article, the DNE and Amerigraphics decisions highlight that the courts have reached inconsistent, and in some instances, polar opposite conclusions when attempting to interpret and apply the existing valuation language contained in business interruption policies.

112. DNE, 834 S.W.2d at 934 (citations omitted).

113. Life Ins. Co. of Ga. v. Johnson, 701 So. 2d 524, 526 (Ala. 1997) (affirming damages awarded to plaintiff by jury holding that insurer engaged in intentional and reckless fraud by selling a worthless Medicare supplement insurance policy); Glazewski v. Coronet Ins. Co., 483 N.E.2d 1263, 1266 (Ill. 1985) ("We are of the opinion that the issuance of coverage by an insurance company in return for a premium is a tacit representation to the consumer that the coverage has value. Assuming for purposes of a motion to dismiss that plaintiffs' allegations that the coverage has no value are true, we find that the insurance company defendants have made a false representation as to the value of the coverage by issuing it without disclosing that it had no value."). 


\section{Courts' Confusion Regarding the Evidentiary Standard Under}

\section{Which Business Interruption Losses Must be Proven}

Although the courts do not agree on how the existing standard valuation language should be interpreted or applied to business interruption losses, there is one consistency in the case law-the courts consistently are confused regarding the evidentiary standard to apply to business interruption claims. ${ }^{114}$ This is not surprising because a business interruption loss valuation is an inherently speculative exercise under the existing policy language. Thus, what should the burden of proof be regarding a speculative damages claim?

Consider again the applicable language found in many business interruption policies today:

In determining the amount of gross earnings covered hereunder for the purposes of ascertaining the amount of loss sustained, due consideration shall be given to the experience of the business before the date of the damage or destruction and to the probable experience thereafter had no loss occurred. ${ }^{115}$

Under this language, the policyholder is asked to prove what the "probable" experience would have been if the loss had not occurred. ${ }^{116}$ In short, the policyholder must prove what its hypothetical earnings and expenses would have been.

114. Polytech, Inc. v. Affiliated FM Ins. Co., 21 F.3d 271, 276 (8th Cir. 1994) (finding business interruption losses must be proven "with reasonable certainty" and "without resorting to speculation"); E. Associated Coal Corp. v. Aetna Cas. \& Sur. Co., 632 F.2d 1068, 1074 (3d Cir. 1980) (holding policyholder has burden of providing non-speculative evidence regarding amount of its loss); Dictiomatic, Inc. v. U.S. Fid. \& Guar. Co., 958 F. Supp. 594, 603 (S.D. Fla. 1997) (holding policyholder that introduced "contradictory projections" regarding its alleged business interruption loss failed to meet its burden of proof); Howard Stores Corp. v. Foremost Ins. Co., 441 N.Y.S.2d 674, 676 (N.Y. Sup. Ct. 1981) (finding policyholder failed to meet its burden of proving its loss was due to business interruption rather than other causes).

115. Finger Furniture Co. v. Commonwealth Ins. Co., 404 F.3d 312, 314 (5th Cir. 2005) (emphasis added). See also cases cited supra notes 44, 67.

116. Finger Furniture, 404 F.3d at 314. 
Some commentators have described the inherently speculative nature of business interruption loss valuations as follows:

Calculating lost income is considerably more conceptual and theoretical than evaluating and determining replacement or repair of damaged property. Business interruption evaluation often involves theoretical calculations that require significant and difficult projections such as a projection of the period of interruption and of the business that would have been conducted during the period of interruption. Adjustment of a business interruption loss therefore often requires the parties to apply the terms of the policy against an estimate of what the business would have earned had the loss not occurred. The exercise is challenging because it requires "proof" of something which never occurred but what should have occurred but for an interrupting event. $^{117}$ $\ldots$

As John F. Kennedy said, "I dream of things that never were," [thus, we] similarly acknowledge that calculating lost income is, by definition, speculative. ${ }^{118}$

Not surprisingly, the fact that business interruption loss valuations are inherently speculative under the existing policy language has caused the courts some consternation when trying to apply traditional evidentiary standards of proof to such claims. ${ }^{119}$ On the one hand, it is hornbook law that damages should be proven to a "reasonable degree of certainty." "120 Yet, how does one prove to a reasonable

117. Lawrence T. Bowman \& Kendall K. Hayden, A Practical Guide to Evaluating Contingent Business Interruption Losses, in NEW APPLEMAN ON INSURANCE, 49, 50 (2008) (footnotes omitted).

118. Id. at 66 (citing Jess B. Millikan, Practice Tips: Time Element Losses During Catastrophes, 31 BRIEF 52 (2002)).

119. See, e.g., Polytech, Inc. v. Affiliated FM Ins. Co., 21 F.3d 271 (8th Cir. 1994); E. Associated Coal Corp. v. Aetna Cas. \& Sur. Co., 632 F.2d 1068 (3d Cir. 1980).

120. Harbor House Condo. Ass'n v. Mass. Bay Ins. Co., 915 F.2d 316, 318 (7th Cir. 1990); ATACS Corp. v. Trans World Commc'ns, 155 F.3d 659, 669 (3d Cir. 1998) (“[A]n injured party need only prove damages with reasonable certainty."). See also LEE R. RUSS \& THOMAS F. SEGALLA, COUCH ON INSURANCE $§ 175: 64$ (3d ed. 2005) ("But there can be no recovery where the loss cannot be determined within reasonable certainty."). 
degree of certainty something that is an inherently speculative valuation regarding the earnings and expenses a policyholder would have had in the hypothetical world in which the loss did not occur? Several courts' decisions seem to suggest that, at least based upon the facts presented in the cases at issue, policyholders may not be able to do so. ${ }^{121}$

The Third Circuit's opinion in Eastern Associated Coal Corp. v. Aetna Casualty \& Surety Co. ${ }^{122}$ is illustrative of this point. In Eastern, the policyholder was a coal mine operator. ${ }^{123}$ The policyholder produced different classifications of coal such as low sulphur and high sulphur coal that are used in different manufacturing processes. ${ }^{124}$ The price for the coal depended upon its sulphur content, which was impacted by a treatment done to the coal known as "washing." 125 A fire caused the interruption of coal production for a year. ${ }^{126}$ When valuing the policyholder's business interruption loss, the parties disputed what percent of the lost coal sales would have been high sulphur versus low sulphur coal. ${ }^{127}$

At trial, the jury found in favor of the policyholder. ${ }^{128}$ The trial court nonetheless entered a judgment notwithstanding the verdict in favor of the insurer because it thought the evidence supporting the policyholder's claim was too "speculative."129 The Third Circuit agreed. ${ }^{130}$ In explaining its holding, the Third Circuit stated:

[W]e hold that the evidence of the sulphur content of coal in the mine alone was insufficient for the jury to determine the sulphur content at the time of delivery. Without evidence of the effectiveness of the washing process, the jury could only speculate concerning the sulphur content at the time of delivery.

121. See, e.g., Polytech, 21 F.3d 271; E. Associated Coal Corp., 632 F.2d 1068.

122. E. Associated Coal Corp., 632 F.2d 1068.

123. Id. at 1070.

124. $I d$.

125. Id. at 1073 .

126. Id. at 1071 .

127. Id. at $1071-72$.

128. E. Associated Coal Corp., 632 F.2d at 1072.

129. Id.

130. Id. at 1074. 
There is no evidence from which the jury could infer the effectiveness of washing. It was [the policyholder's] burden to provide evidence from which its claim can be established. ${ }^{131}$

In short, the court required the policyholder to prove to a reasonable certainty what apparently could not be proven-what the sulfur content in the coal that would have been mined, treated, and sold would have been if the fire had not occurred. ${ }^{132}$

Similarly, in Polytech, Inc. v. Affiliated FM Insurance Co., ${ }^{133}$ an explosion and fire caused an interruption in the policyholder's plexiglass manufacturing business. ${ }^{134}$ The parties disputed the amount of, and approach to proving, the business interruption loss. ${ }^{135}$ On the morning the trial was scheduled to commence, the trial court entered summary judgment in favor of the policyholder. ${ }^{136}$

On appeal, the Eighth Circuit reversed and remanded the case for trial because it found there was "conflicting evidence as to the existence of future earnings" 137 Notably, in remanding the case, the court announced the following evidentiary standard for the policyholder to satisfy: "“[T]o obtain a damage award for lost profits at trial, [the policyholder] must produce evidence that provides an adequate basis for estimating lost profits with reasonable certainty. Proof of actual facts which present a basis for a rational estimate of damages without resorting to speculation is required." 138 In short, the policyholder was instructed on remand to prove, without speculative evidence, what would have happened had its business not been interrupted. ${ }^{139}$

Cases such as the Eastern and Polytech decisions raise the following question: can a policyholder prove, to a "reasonable

131. Id.

132. Id.

133. Polytech, Inc. v. Affiliated FM Ins. Co., 21 F.3d 271, 272 (8th Cir. 1994).

134. Id.

135. Id.

136. Id. at $272-73$.

137. Id. at 277.

138. Id. at 276 (quoting Manor Square, Inc. v. Heartthrob of Kan. City, Inc., 854 S.W.2d 38, 44 (Mo. Ct. App. 1993)).

139. Polytech, 21 F.3d at 276. 
certainty," the reality of a fictional situation? Of course they cannot. Nor, as is discussed below in Part IV.A.1., should they be expected or required to do so.

\section{PRINCIPLES OF InSURANCE POLICY InTERPRETATION RELEVANT TO VALUING BUSINESS INTERRUPTION LOSSES}

When courts are asked to interpret and apply policy language such as the loss valuation language quoted above, three well-established rules of policy interpretation are particularly relevant to the analysis: (1) contra proferentem, (2) the "reasonable expectations" doctrine, and (3) construction of the policy as a whole. ${ }^{140}$

\section{A. The Doctrine of Contra Proferentem}

It is hornbook insurance law that because insurers are the drafters of policy language such as the loss valuation provisions contained in business interruption insurance policies, ${ }^{141}$ the doctrine of contra proferentem applies, which means any ambiguities in the policy language should be construed against the insurers and in favor of coverage. $^{142}$ The test under many states' laws for determining

140. See discussion infra Part III.A-C.

141. See supra note 9 .

142. Christopher C. French, The "Ensuing Loss" Clause in Insurance Policies: The Forgotten and Misunderstood Antidote to Anti-Concurrent Causation Exclusions, 13 NEV. L.J. 215, $223-24$ (2012). See also Crane v. State Farm Fire \& Cas. Co., 485 P.2d 1129, 1130 (Cal. 1971) ("Any ambiguity or uncertainty in an insurance policy is to be resolved against the insurer."); Phillips Home Builders, Inc. v. Travelers Ins. Co., 700 A.2d 127, 129 (Del. 1997) ("If there is an ambiguity, however, the contract language is "construed most strongly against the insurance company that drafted it."'); Crawford v. Prudential Ins. Co. of Am., 783 P.2d 900, 904 (Kan. 1989) ("Since an insurer prepares its own contracts, it has a duty to make the meaning clear, and if it fails to do so, the insurer, and not the insured, must suffer.”); RPM Pizza, Inc. v. Auto. Cas. Ins. Co., 601 So.2d 1366, 1369 (La. 1992) (“[A]ny ambiguity must be construed against the insurance company and in favor of the reasonable construction that affords coverage."); Am. Bumper and Mfg. Co. v. Hartford Fire Ins. Co., 550 N.W.2d 475, 480 (Mich. 1996) (" $[I] n$ construing insurance contracts, any ambiguities are strictly construed against the insurer to maximize coverage."); Ohio Cas. Ins. Co. v. Flanagin, 210 A.2d 221, 226 (N.J. 1965) ("If the controlling language will support two meanings, one favorable to the insurer, and the other favorable to the insured, the interpretation sustaining coverage must be applied.") (quoting Mazzilli v. Accident \& Cas. Ins. Co, of Winterthur, Switz., 170 A.2d 800, 803-04 (N.J. 1961)); Gomolka v. State Auto Mut. Ins. Co., 436 N.E.2d 1347, 1348-49 (Ohio 1982) ("Policies of insurance, which are in language selected by the insurer and which are reasonably open to different interpretations, will be construed most favorably for the insured.") (quoting Home Indem. Co. v. Village of Plymouth, 64 N.E.2d 248, 250 
whether policy language is ambiguous is whether the provisions at issue are reasonably or fairly susceptible to different interpretations or meanings. ${ }^{143}$ If the policyholder and insurer both offer reasonable interpretations of the policy language, then the policy language is ambiguous and should be construed in favor of coverage. ${ }^{144}$ Where the controversy involves a phrase that the insurers have failed to define and has generated many lawsuits with varying results, common sense dictates that the policy language must be ambiguous. $^{145}$

(Ohio 1945)); Elizabeth K. Ainslie et al., Business Insurance Law and Practice Guide $\S 2.02(1)$ (2013); BARRY R. OSTRAGER \& THOMAS R. NEWMAN, HANDBOOK ON INSURANCE COVERAGE DisPUTES $§ 1.03$ (c), at 28-30 (9th ed. 1998); 2 ERIC M. HOLMES \& MARK S. RHODES, APPLEMAN ON INSURANCE $§ 6.1$, at 132-33 (2d ed. 1996); 2 ROWLAND H. LONG, THE LAW OF LIABILITY INSURANCE $\S 16.06$ (Supp. 1988); RusS \& SEgAlla, supra note 120, § 22:14; JeFFrey W. STEMPEL INTERPRETATION OF INSURANCE CONTRACTS: LAW AND STRATEGY FOR INSURERS AND POLICYHOLDERS § 5.1, at 173 (1994); David B. Goodwin, Disputing Insurance Coverage Disputes, 43 STAN. L. REV. 779, 795-96 (1991) (reviewing BARRY R. OSTRAGER \& THOMAS R. NEWMAN, HANDBOOK ON INSURANCE COVERAGE DISPUTES (3d ed. 1990)).

143. HOLMES \& RHODES, supra note $142, \S 6.1$, at 169 (insurer has burden of establishing that insurer's interpretation is the only fair interpretation of contract); LONG, supra note 142, §16.06, at 1632. See also New Castle Cnty. Del. v. Nat'l Union Fire Ins. Co. of Pittsburgh, 243 F.3d 744, 750 (3d Cir. 2001) ("“The settled test for ambiguity is whether the provisions in controversy are reasonably or fairly susceptible of different interpretations or may have two or more different meanings."') (quoting New Castle Cnty. Del. v. Nat'l Union Fire Ins. Co. of Pittsburgh, 174 F.3d 338, 344 (3d Cir. 1999)); Shepard v. Calfarm Life Ins. Co., 7 Cal. Rptr. 2d 428, 432-33 (Cal. Ct. App. 1992) (finding a policy provision is ambiguous when more than one construction exists and the burden of proving one reasonable construction falls to the insurer); High Country Assocs. v. N.H. Ins. Co., 648 A.2d 474, 476 (N.H. 1994) ("If the language of the policy reasonably may be interpreted more than one way and one interpretation favors coverage, an ambiguity exists in the policy that will be construed in favor of the insured and against the insurer."); Salem Grp. v. Oliver, 607 A.2d 138, 139 (N.J. 1992) ("When a policy fairly supports an interpretation favorable to both the insured and the insurer, the policy should be interpreted in favor of the insured."); Harris, Jolliff \& Michel, Inc. v. Motorists Mut. Ins. Co., 255 N.E.2d 302, 307 (Ohio Ct. App. 1970) (finding that where insurer and insured each present reasonable interpretations of exclusion, exclusion is ambiguous and must be interpreted in favor of the insured); Bartlett v. Amica Mut. Ins. Co., 593 A.2d 45, 47 (R.I. 1991) (noting ambiguity if clause has more than one reasonable meaning); Bonner v. United Servs. Auto. Ass'n, 841 S.W.2d 504, 506 (Tex. Ct. App. 1992) ("The court must adopt the construction of an exclusionary clause urged by the insured as long as the construction is not unreasonable, even if the construction urged by the insurer appears to be more reasonable or a more accurate reflection of the parties' intent.").

144. Bonner, 841 S.W.2d at 506.

145. New Castle Cnty. Del., 243 F.3d at 756 (finding ambiguity where the contested phrase was not defined and had been interpreted differently by various courts); Sec. Ins. Co. v. Investors Diversified Ltd., 407 So. 2d 314, 316 (Fla. Dist. Ct. App. 1981) ("The insurance company contends that the language is not ambiguous, but we cannot agree and offer as proof of that pudding the fact that the Supreme Court of California and the Fifth Circuit in New Orleans have arrived at opposite conclusions from a study of essentially the same language."); Crawford v. Prudential Ins. Co. of Am., 783 P.2d 900, 908 (Kan. 1989) (" $[R]$ eported cases are in conflict, the trial judge and the Court of Appeals reached 
Further, because insurers seek to invoke the valuation provisions as a way of limiting the amount of coverage to be provided for losses that are unquestionably insured, the language should be viewed as akin to an exclusion, which means: (1) it should be narrowly construed against the insurer, and (2) the insurer has the burden of proving its applicability. ${ }^{146}$ Indeed, numerous courts have held that exclusions will not be interpreted and applied in such a way as to swallow the basic coverages provided under a policy. ${ }^{147}$ So how does contra proferentem apply in the context of interpreting and applying the valuation provisions in business interruption insurance? As is discussed above and below in Part IV, an ambiguous insurance policy provision is one that has more than one reasonable meaning. ${ }^{148}$ Thus, when one attempts to interpret and apply the valuation

different conclusions and the justices of this court [disagree] .... Under such circumstances, the clause is, by definition, ambiguous and must be interpreted in favor of the insured."); Allstate Ins. Co. v. Hartford Accident \& Indem. Co., 311 S.W.2d 41, 47 (Mo. Ct. App. 1958) ("Since we assume that all courts adopt a reasonable construction, the conflict is of itself indicative that the word as so used is susceptible of at least two reasonable interpretations, one of which extends the coverage to the situation at hand."); George H. Olmsted \& Co. v. Metro. Life Ins. Co., 161 N.E. 276, 276 (Ohio 1928) ("Where the language of a clause used in an insurance contract is such that courts of numerous jurisdictions have found it necessary to construe it and in such construction have arrived at conflicting conclusions as to the correct meaning, intent and effect thereof, the question whether such clause is ambiguous ceases to be an open one."); Cohen v. Erie Indem. Co., 432 A.2d 596, 599 (Pa. Super. Ct. 1981) ("The mere fact that [courts differ on the construction of the provision] itself creates the inescapable conclusion that the provision in issue is susceptible to more than one interpretation."). See generally Charles C. Marvel, Annotation, Division of Opinion Among Judges on Same Court or Among Other Courts or Jurisdictions Considering Same Question, as Evidence that Particular Clause of Insurance Policy is Ambiguous, 4 A.L.R. 4TH 1253 (1981).

146. SCSC Corp. v. Allied Mut. Ins. Co., 536 N.W.2d 305, 313 (Minn. 1995) (insurer has burden to prove the applicability of an exclusion as an affirmative defense); Cont'l Ins. Co. v. Louis Marx \& Co., 415 N.E.2d 315, 317 (Ohio 1980) (defense has burden of proving defense based upon exclusion); Brown v. Snohomish Cnty. Physicians Corp., 845 P.2d 334, 340 (Wash. 1993) (once insured has made a prima facie case that there is coverage, burden shifts to the insurer to prove an exclusionary provision applies). See also Holmes \& RHODES, supra note 142, § 6.1, at 139-42; RUSS \& SEgALla, supra note 120, $\S 22: 31$.

147. Tews Funeral Home, Inc. v. Ohio Cas. Ins. Co., 832 F.2d 1037, 1045 (7th Cir. 1987) (finding policy excluding acts explicitly covered in prior section of policy is construed against insurer); Alstrin v. St. Paul Mercury Ins. Co., 179 F. Supp. 2d 376, 390 (D. Del. 2002) (construing ambiguities against insurer in order to reduce the insurer's incentive to draft policy language where certain provisions purport to give coverage while other clauses "take that very coverage away"); Titan Indem. Co. v. Newton, 39 F. Supp. 2d 1336, 1348 (N.D. Ala. 1999) (finding coverage even though "the limitations of [the] policy completely swallow up the insuring provisions"); Bailer v. Erie Ins. Exch., 687 A.2d 1375, 1380 (Md. 1997) (finding that "[i]f the exclusion totally swallows the insuring provision," then such provisions create the greatest form of ambiguity, and the insurer is obliged to provide coverage).

148. See supra note 143 
provisions of business interruption insurance - as evidenced by the fact no loss valuation formula is contained in the provisions, many of the terms are not defined, and the courts have struggled to even determine what evidence should be considered when valuing business interruption losses - it becomes apparent that the provisions are ambiguous when applied. ${ }^{149}$ Consequently, they should be construed against insurers. ${ }^{150}$

\section{B. The "Reasonable Expectations" Doctrine}

Another staple of insurance law is that a policy should be interpreted in such a way as to fulfill the "reasonable expectations" of the policyholder. ${ }^{151}$ A seminal article regarding the "reasonable expectations" doctrine was written more than forty years ago by then Professor Robert Keeton. ${ }^{152}$ In his subsequent treatise, then Judge Keeton summarized the doctrine as follows:

149. See infra Parts III, IV.

150. See supra notes $142-43$ and accompanying text.

151. AINSLIE, supra note 142, § 2.02(1)(4); French, supra note 142, at 225-26; ROBERT E. KEETON \& ALAN I. WIDISS, INSURANCE LAW § 6.3(a)(3), at 633-34 (1988); LONG, supra note 142, § 16.07, at 1643; OSTRAGER \& NEWMAN, supra note 142, § 1.03(b)(2)(B), at 22-27 (identifying courts in thirty-eight jurisdictions that have expressed support for, or applied a form of, the reasonable expectations doctrine); RUSS \& SEGALLA, supra note 120, § 22.11; STEMPEL, supra note 142, § 11.1, at 312. See also AIU Ins. Co. v. Super. Ct. of Santa Clara Cnty., 799 P.2d 1253, 1264 (Cal. 1990) (interpreting ambiguous coverage clauses of insurance policies broadly to protect the objectively reasonable expectations of the insured); Roland v. Ga. Farm Bureau Mut. Ins. Co., 462 S.E.2d 623, 625 (Ga. 1995) ("A contract of insurance should be strictly construed against the insurer and read in favor of coverage in accordance with the reasonable expectations of the insured."); Corgatelli v. Globe Life \& Accident Ins. Co., 533 P.2d 737, 741 (Idaho 1975) (applying reasonable expectations doctrine notwithstanding conclusion that the provision was unambiguous); Mills v. Agrichemical Aviation, Inc., 250 N.W.2d 663, 671-73 (N.D. 1977) (holding doctrine of reasonable expectations is properly invoked to discern intentions of parties and impose liability on insurer); A.B.C. Builders, Inc. v. Am. Mut. Ins. Co., 661 A.2d 1187, 1190 (N.H. 1995) (“"'[T]he policy language must be so clear as to create no ambiguity which might affect the insured's reasonable expectations."') (quoting Cacavas v. Me. Bonding \& Cas. Co., 512 A.2d 423, 425 (N.H. 1986)); Fed. Ins. Co. v. Century Fed. Sav. \& Loan Ass'n, 824 P.2d 302, 308 (N.M. 1992) (stating that courts will give effect to policyholder's reasonable expectations in construing policy language); Nat'l Mut. Ins. Co. v. McMahon \& Sons, Inc., 356 S.E.2d 488, 495-96 (W. Va. 1987) (stating that courts will apply reasonable expectations doctrine to construe the policy in a manner that a reasonable person standing in the shoes of the insured would expect the language to mean, "even though painstaking study of the policy provisions would have negated those expectations") (quoting Robert Keeton, Insurance Law Rights at Variance With Policy Provisions, 83 HARV. L. ReV. 961, 967 (1970)). 152. Robert Keeton, Insurance Law Rights at Variance With Policy Provisions, 83 Harv. L. Rev. 961, 966-77 (1970). 
In general, courts will protect the reasonable expectations of applicants, insureds, and intended beneficiaries regarding the coverage afforded by insurance contracts even though a careful examination of the policy provisions indicates that such expectations are contrary to the expressed intention of the insurer. ${ }^{153}$

As another commentator more recently stated, "In other words, even when the policy language unambiguously precludes coverage, under certain circumstances, courts will hold that coverage exists."

Stated differently, the policyholder should receive in coverage what it objectively can reasonably expect to receive even if the insurer can point to some policy language that supports the insurer's position that the claim at issue should not be covered or coverage should be limited. ${ }^{155}$ Thus, for example, a policyholder who buys

153. KEETON \& WIDISS, supra note $151, \S 6.3(\mathrm{a})(3)$, at 633 . For commentary regarding the reasonable expectations doctrine, see Kenneth S. Abraham, Judge-Made Law and Judge-Made Insurance: Honoring the Reasonable Expectations of the Insured, 67 VA. L. REV. 1151 (1981); Roger C. Henderson, The Doctrine of Reasonable Expectations in Insurance Law After Two Decades, 51 OHIO ST. L.J. 823 (1990) (providing a detailed historical account of the doctrine and asserting that the doctrine is principled and can be applied within justifiable guidelines); Robert H. Jerry, II, Insurance, Contract, and the Doctrine of Reasonable Expectations, 5 ConN. INS. L.J. 21, 21 (1998) (discussing the doctrine as conceptualized by Keeton); William A. Mayhew, Reasonable Expectations: Seeking a Principled Application, 13 PEPP. L. REv. 267, 287-96 (1986) (formulating standards for applying the doctrine); Mark C. Rahdert, Reasonable Expectations Reconsidered, 18 ConN. L. REv. 323, 392 (1986) (arguing for refinements to the doctrine in response to the fading appeal that the doctrine holds for courts and commentators and contending that courts should "discard their unfortunate tendency to speak the platitudes of reasonable expectations without undertaking a careful and systematic analysis"); Daniel Schwarcz, A Products Liability Theory for the Judicial Regulation of Insurance Policies, 48 WM. \& MARY L. REV. 1389, 1395 (2007) (criticizing the reasonable expectations doctrine and arguing that the case law endorsing the doctrine is "confused and inconsistent"). While there is relatively broad acceptance of the doctrine, judicial interpretation and application of the doctrine is variable. See Jeffrey W. Stempel, Unmet Expectations: Undue Restriction of the Reasonable Expectations Approach and the Misleading Mythology of Judicial Role, 5 ConN. INS. L.J. 181, 191 (1998) (describing judicial approaches and noting both liberal and narrow approaches among the numerous states that have adopted the doctrine); Peter Nash Swisher, A Realistic Consensus Approach to the Insurance Law Doctrine of Reasonable Expectations, 35 TORT \& INS. L.J. 729 (2000) (exploring judicial responses and proposing a middle ground approach).

154. Francis J. Mootz, III, Insurance Coverage of Employment Discrimination Claims, 52 U. MIAMI L. REV. 1, 22, (1997).

155. The reasonable expectations doctrine is rooted in the fact that insurance policies generally are contracts of adhesion drafted by insurers and offered to consumers on a take-it-or-leave-it basis. See, e.g., KeETON \& WIDISS, supra note 151, at 967; Friedrich Kessler, Contracts of Adhesion-Some Thoughts About Freedom of Contract, 43 Colum. L. REv. 629, 629, 632 (1943); Todd D. Rakoff, 
business interruption insurance to protect its earnings stream against business interruptions caused by catastrophic perils, such as hurricanes and tornadoes, reasonably can expect that it will be reimbursed for its lost business earnings when a hurricane or tornado interrupts its business.

So what does this mean in the context of valuing business interruption loss claims? As is discussed below in Part IV, because the valuation provisions are, at best, ambiguous, one arguably does not even need to apply the reasonable expectations doctrine. The ambiguities in the language should be construed in favor of the policyholder. ${ }^{156}$ Nonetheless, even if the provisions were somehow viewed as unambiguous, a policyholder who buys business interruption insurance reasonably can expect to receive from its insurer, for the period of interruption, the business earnings it had been receiving prior to the catastrophe. In other words, courts should not permit insurers to accept premiums for business interruption insurance, but then, when a claim is presented, pay the policyholder nothing or only a fraction of its business interruption loss. To do so would render the coverage provided to the business owner under the policy illusory, which is impermissible. ${ }^{157}$

Contracts of Adhesion: An Essay in Reconstruction, 96 HARV. L. REV. 1173, 1226 (1983); Schwarcz, supra note 153, at 1401-02; Peter Nash Swisher, Symposium Introduction, 5 ConN. INS. L.J. 1, 5 (1998) (introducing the Association of American Law Schools program entitled "The Insurance Law Doctrine of Reasonable Expectations After Three Decades").

156. Consol. Cos. v. Lexington Ins. Co., No. 06-4700, 2009 U.S. Dist. LEXIS 8542, at*25 (E.D. La. Jan. 23, 2009) (citing La. Maint. Servs., Inc. v. Certain Underwriters at Lloyd's of London, 616 So. 2d 1250, 1252 (La. 1993))

157. See supra note 147. See also Bowersox Truck Sales \& Serv., Inc. v. Harco Nat'l Ins. Co., 209 F.3d 273, 277-78 (3d Cir. 2000) (rejecting insurer's interpretation of policy's two-year limitation period where interpretation would have rendered coverage illusory); Harris v. Gulf Ins. Co., 297 F. Supp. 2d 1220, 1226 (N.D. Cal. 2003) (rejecting insurer's interpretation of exclusion in policy because it "would render the coverage provided by the policy illusory"); Alstrin v. St. Paul Mercury Ins. Co., 179 F. Supp. 2d 376, 398 (D. Del. 2002) (rejecting a D\&O insurer's interpretation of the policy's deliberate fraud exclusion where, if applied, "there would be little or nothing left to that coverage" because "[n]o insured would expect such limited coverage from a policy that purports to cover all types of securities fraud claims"); Atofina Petrochemicals, Inc. v. Cont'l Cas. Co., 185 S.W.3d 440, 444-45 (Tex. 2005) (rejecting insurer's interpretation of additional insured endorsement because it "would render coverage under the endorsement largely illusory"). 


\section{Construction of the Policy as a Whole}

Another policy interpretation principle applicable to the valuation of business interruption losses "provides that, if possible, the policy should be interpreted in a way that reconciles [the] various provisions [of the policy] and attempts to give effect to all of [the provisions]" while keeping the general purpose of the insurance in mind. ${ }^{158}$ In the context of business interruption insurance, this means that the courts should interpret the various components of the valuation provisions in light of the purpose of business interruption insurance. As is discussed above, the basic purpose of business interruption insurance is to protect the policyholder from lost earnings during periods of interruption. ${ }^{159}$ If that purpose is not fulfilled when the policy language at issue is interpreted and applied, then the insurance coverage purchased may impermissibly become illusory. ${ }^{160}$

\section{How Business INTERRUPTION LOSSES SHOULD BE VALUED}

In this part of the Article, the problems with the courts' various approaches to interpreting and applying the policy language regarding the valuation of business interruption losses are discussed. Then, an interpretation regarding the existing valuation language under the rules of policy interpretation is offered. Finally, a proposal

158. French, supra note 142, at 227. See also O.C.G.A. § 13-2-2(4) (West 2010) (contracts should be interpreted as a whole); Rothenberg v. Lincoln Farm Camp, Inc., 755 F.2d 1017, 1019 (2d Cir. 1985) ("[A]n interpretation that gives a reasonable and effective meaning to all the terms of a contract is generally preferred to one that leaves a part unreasonable or of no effect[.]"); Fireman's Fund Ins. Co. v. Allstate Ins. Co., 286 Cal. Rptr. 146, 155-56 (Ct. App. 1991) ("In short, an insurance contract is to be construed in a manner which gives meaning to all its provisions in a natural, reasonable, and practical manner, having reference to the risk and subject matter and to the purposes of the entire contract.") (quoting State Farm Mut. Auto. Ins. Co. v. Crane 217 Cal. App. 3d 1127, 1132 (Ct. App. 1990)); Barrett v. Farmers Ins. Grp., 220 Cal. Rptr. 135, 137 (Ct. App. 1985) ("The [insurance contract] is to be construed in a manner which gives a reasonable meaning to all its provision in a natural, reasonable and praticalmanner, [sic] having reference to the risk and subject matter and to the purposes of the entire contract.”) (quoting Home Indem. Co. v. Leo L. Davis, Inc., 79 Cal. App. 3d 863, 869 (Ct. App. 1978)); Weiss v. Bituminous Cas. Corp., 319 N.E.2d 491, 495 (Ill. 1974) (provisions in an insurance policy should be interpreted in context of entire policy); Welborn v. Ill. Nat. Cas. Co., 106 N.E.2d 142, 143 (Ill. App. Ct. 1952) ("[T] give a meaning to all provisions, so far as possible, which will render them consistent and operative.").

159. See supra note 6.

160. See supra notes 147, 157. See also discussion infra Part IV. 
regarding how business interruption losses should be valued in the future is presented.

\section{A. The Problems with the Existing Framework}

There are numerous problems with the existing valuation language in business interruption policies. Consequently, the courts' attempts to apply this language has resulted in a body of case law that is inconsistent, unpredictable, and leads to the inefficient resolution of business interruption claims.

\section{Business Interruption Loss Valuations are Inherently \\ Speculative so They Cannot be Proven with "Reasonable Certainty"}

As an initial matter, because valuing a business interruption loss is an inherently speculative exercise under the existing policy language, the courts should not be requiring policyholders to prove to a reasonable degree of certainty the amount the policyholder would have earned during the period of interruption. ${ }^{161}$ To do so imposes an arguably insurmountable evidentiary burden on the policyholder under the current valuation language. ${ }^{162} \mathrm{~A}$ business interruption loss calculation under the existing policy language is a hypothetical exercise - a projection. One cannot prove what would have happened with "reasonable certainty" if a business's operation had not been interrupted. No one knows with reasonable, or unreasonable, certainty what would have happened. If people could predict the future with reasonable certainty, many accidents and catastrophes could and would be avoided.

Indeed, the notion that a policyholder should be able to appear in court and demonstrate exactly how many orders it would have received if its business had been operational is not grounded in reality. When a business is shut down, the orders stop coming as soon as customers learn of the interruption. Customers do not call the

161. See supra Part II.D.

162. Id. 
policyholder and say, "if your business were still operating, I would have ordered X widgets." The phones simply stop ringing. The customers take their business elsewhere.

Consequently, policyholders typically do not have documentation of "lost" orders. Nor can or would most policyholders present customers at trial who would testify that they would have ordered a specific amount of product or services if the business had been operational. Customers do not keep track of orders they do not place. Thus, requiring policyholders to prove such matters to a "reasonable degree of certainty" is simply inconsistent with the way the business world works and, in many instances, is impossible.

Moreover, it would be bad business for a policyholder to even attempt to do so. How many customers voluntarily will want to interrupt their professional and personal lives to go to court and testify in an insurance dispute that does not even involve them? Because very few people are interested in putting aside their personal and professional obligations in order to subject themselves to cross examination, it would be bad business for a policyholder to even ask its customers to do so. So what then? Should the policyholder subpoena its uncooperative customers to testify? Doing so may provide the policyholder with a pyrrhic victory ${ }^{163}$ of winning the lawsuit against its insurer but losing its customers.

Putting aside the problems such an evidentiary standard presents for the policyholder, how should a jury even attempt to apply a "reasonable degree of certainty" standard to what is indisputably a hypothetical situation? Indeed, in other contexts where the damages at issue are inherently speculative, such as the valuation of lost goodwill, some courts use a relaxed evidentiary standard of proof where only the fact of damages, but not the amount, must be proven to a reasonable degree of certainty. ${ }^{164}$ For all of these reasons, courts

163. See generally Plutarch, Life of Pyrrhus, in IX Plutarch's Lives 363 (Bernadotte Perrin trans. 1920). The phrase is named after King Pyrrhus of Epirus, whose army suffered irreplaceable casualties in defeating the Romans at Heraclea in $280 \mathrm{BC}$ and Asculum in $279 \mathrm{BC}$ during the Pyrrhic War. Id.

164. Although damages of lost goodwill technically must be proven to a reasonable degree of certainty, "'the doctrine respecting the matter of certainty, properly applied, is concerned more with the fact of damage than with the extent or amount of damage." Lewis River Golf, Inc. v. O.M. Scott \& 
should not require policyholders to prove with "reasonable certainty" what their earnings and costs would have been in the fictional, hypothetical world in which the business interruption did not occur. Instead, as is discussed below in Part IV.C., the loss calculation should be done under fixed formulas that do not require the parties, court, or jury to conduct a "what if" analysis.

\section{Using Only the Policyholder's Historical Financial}

Information to Value Business Interruption Losses Ignores Some of the Valuation Policy Language

In addition, the line of cases, with the Fifth Circuit's decision in Finger Furniture ${ }^{165}$ being the leading example, in which the courts only allow the policyholder's historical financial information to be considered when business interruption losses are calculated, is based upon a selective reading of the valuation language in business interruption policies. ${ }^{166}$ The reasoning of the courts in these cases is that, " $[t]$ he strongest and most reliable evidence of what a business would have done had the catastrophe not occurred is what it had been doing in the period just before the interruption."167 Agreed, but the policy language does not say that.

The valuation provisions provide that "due consideration shall be given to the experience of the business before the date of the damage or destruction and to the probable experience thereafter had no loss occurred." 168 Why would insurers include the italicized language if they really meant that only the experience of the policyholder before the catastrophe should be used to value the loss? If that is what the insurers intended, then it would have been simple enough for the policies to state, "when valuing the loss, only the historical performance of the policyholder shall be considered."

\footnotetext{
Sons, 845 P.2d 987, 990 (Wash. 1993) (emphasis omitted) (quoting Gaasland Co., Inc. v. Hyak Lumber \& Millwork, Inc. 257 P.2d 784, 788 (Wash. 1953)). Damages for lost good will are "not subject to proof of mathematical certainty," and consequently, they only have to be proven " with whatever definiteness and accuracy the facts permit, but no more."” Id. (quoting Official UCC Comment, § 1-106).

165. Finger Furniture Co. v. Commonwealth Ins. Co, 404 F.3d 312 (5th Cir. 2005).

166. See supra Part II.A.

167. Finger Furniture, 404 F.3d at 314.

168. Id. (emphasis added).
} 
Nonetheless, the Fifth Circuit has interpreted the existing policy language to mean only the historical performance of the policyholder shall be considered. ${ }^{169}$ Under the Fifth Circuit's interpretation, the "probable experience had no loss occurred" language is superfluous or, at best, redundant. ${ }^{170}$ Thus, by essentially overriding that policy language, the Fifth Circuit has violated one of the bedrock principles of insurance policy interpretation - that all provisions in the policy should be given effect and construed harmoniously if possible with the purpose of the insurance in mind. ${ }^{171}$ Further, and worse, by construing the language against policyholders in situations where the post-catastrophe economic conditions are favorable to the policyholder, the Fifth Circuit also has violated the fundamental doctrine of policy interpretation, contra proferentem, which dictates that ambiguities in policy language shall be construed in favor of policyholders. $^{172}$

With that said, by rendering the "probable experience had no loss occurred" language essentially meaningless, the Fifth Circuit has simplified the loss valuation analysis because it eliminated one of the issues most hotly contested-what impact the post-catastrophe economic conditions would have had on the policyholder's business if the policyholder's business had not been interrupted. ${ }^{173}$ The postcatastrophe economic conditions for a policyholder can be either greatly enhanced or reduced depending upon the nature of the policyholder's business. For example, after Hurricane Katrina, there was little demand for restaurants on Bourbon Street in New Orleans because tourists stopped going to New Orleans until the area had recovered. ${ }^{174}$ Thus, if one were to consider the post-catastrophe

170. Id.

171. See discussion supra Part III.C.

172. See discussions supra Part III.A and infra Part IV.B.

173. Finger Furniture, 404 F.3d at 314.

174. See, e.g., Russell McCulley, Will Bourbon Street Bring the Tourists Back to New Orleans?, TIME (Aug. 25, 2006), http://www.time.com/time/nation/article/0,8599,1334012,00.html ("Though the areas of most interest to visitors got through Katrina pretty much intact, the haunting images (including tourists trapped in hotels) and constant media attention left over from Katrina has kept the bulk of sightseers from returning."); Kim Severson, New Orleans Watch: Restaurant Reopenings, N.Y. TIMES (Nov. 18, 2005), http://www.nytimes.com/2005/11/18/travel/18webfood.html ("Without tourists, New 
economic conditions for restaurants in New Orleans when valuing his business interruption losses, then such restaurants likely would have had little, if any, business interruption losses because there would not have been many customers patronizing the restaurants even if the restaurants had been operational.

On the other hand, as evidenced by the case law discussed in Part II.B., there was great demand for housing in the New Orleans area after Hurricane Katrina. ${ }^{175}$ Consequently, the rental value of apartments increased post-catastrophe. ${ }^{176}$ Thus, if a policyholder were able to use the higher rental rates when valuing its business interruption loss, then its recovery for its business interruption loss would be higher than it would have been if the policyholder's business had not been interrupted. ${ }^{177}$

In addition, by eliminating consideration of the post-catastrophe economic conditions, the Fifth Circuit also effectively eliminated the need for expert witnesses to opine regarding the impact the state of the economy would have had on the policyholder's business during the period of interruption. ${ }^{178}$ Indeed, since the 2008 financial meltdown, it has been common for insurers to contend policyholders that suffered a business interruption in the past few years did not actually suffer a loss due to the interruption because they would have been operating at a loss even if their businesses had not been interrupted. ${ }^{179}$ Thus, by limiting the relevant evidence allowed to value business interruption losses to the pre-loss time period, the state of the economy during the period of interruption becomes irrelevant under the Fifth Circuit's approach.

In short, although the Fifth Circuit should be lauded for attempting to simplify business interruption loss calculations, the way the Fifth

\footnotetext{
Orleans is losing more than $\$ 15$ million a day in direct revenue, according to the governor's office.”).

175. See supra note 67.

176. Id.

177. Id

178. Finger Furniture, 404 F.3d at 314.

179. See, e.g., Penford Corp. v. Nat'l Union Fire Ins. Co. of Pittsburgh, No. 09-CV-13-LRR, 2010 WL 2509985, at*11 (N.D. Iowa June 17, 2010) (allowing insurers' expert to offer an opinion regarding the effect the recession would have had on the policyholder's business during the period of interruption).
} 
Circuit has done so is inconsistent with the existing valuation policy language and the rules of policy interpretation.

\section{Consideration of the Post-Catastrophe Economic Conditions}

Can Lead to Unfair Results and Factual Disputes That Must be

Tried

Also, allowing the post-loss economic conditions to be considered when valuing business interruption losses often creates: (1) windfall gains or unfair losses for the policyholder and (2) factual disputes because the parties often do not agree on the state of the economy or its impact on the policyholder's business.

If the result in a case is that the policyholder obtains a windfall gain or an unfair loss, then the legal system has failed in that case. As is discussed above, the purpose of business interruption insurance is to place the policyholder in the same position it would have been if its business had not been interrupted. ${ }^{180}$ Often times, however, the catastrophe that causes the business interruption changes the economy in the area of the catastrophe. Consequently, when the postcatastrophe economic conditions are considered when calculating the policyholder's business interruption loss, the policyholder may receive a windfall gain or an unfairly low loss valuation.

Again, the New Orleans area following Hurricane Katrina is a prime example of this phenomenon. As previously noted, certain businesses, such as restaurants in the French Quarter, had very little business immediately following Hurricane Katrina because tourists stopped going to New Orleans. ${ }^{181}$ If the post-catastrophe economic conditions of New Orleans were considered in valuing restaurants' business interruption losses after the hurricane passed, then they arguably had little or no losses because there was little or no demand for their services. It obviously would be unfair; however, if no business interruption loss payments were made to restaurants, because they clearly suffered massive losses due to Hurricane Katrina and they were not in the same position they would have been

180. See supra note 6 .

181. McCulley, supra note 174. 
had Hurricane Katrina missed New Orleans. Thus, by considering the post-catastrophe economic conditions in that situation, the purpose of business interruption insurance would not be fulfilled.

Conversely, the demand in the housing market in southern Louisiana increased after Hurricane Katrina. ${ }^{182}$ Thus, if a landlord's business interruption losses following Hurricane Katrina were calculated using the post-Katrina rental values, then the landlord would receive a windfall gain because it would be placed in a better position than it would have been if no disaster had occurred and its business had not been interrupted. Indeed, the landlord would actually recover more for the period of interruption than it would have if no catastrophe had occurred.

In addition, the factual disputes that arise when discussing the state of the post-catastrophe economy increases the chances a case will need to be tried, ${ }^{183}$ which places an unnecessary burden on the legal system. If a case has to be tried, it often means the outcome of the case is unpredictable because the parties would settle if they agreed on the outcome of the trial. ${ }^{184}$ As evidenced by the tapestry of inconsistent decisions discussed above in Part III.C., the outcomes of

182. See, e.g., Sher v. Lafayette Ins. Co., 973 So.2d 39, 57 (La. Ct. App. 2007).

183. See, e.g., Alabama v. North Carolina, 130 S. Ct. 2295, 2308 (2010) (“[S]ummary judgment is appropriate where there 'is no genuine issue as to any material fact' and the moving party is 'entitled to judgment as a matter of law."') (quoting FED. R. CIV. P. 56(c)); Montgomery v. Barrow, 692 S.E.2d 351,353 (Ga. 2010) ("[T]he moving party must demonstrate that there is no genuine issue of material fact and that the undisputed facts, viewed in the light most favorable to the nonmoving party, warrant judgment as a matter of law.") (quoting Lau's Corp. v. Haskins, 405 S.E.2d 474, 475 (Ga. 1991)); UT Med. Grp., Inc. v. Vogt, 235 S.W.3d 110, 119 (Tenn. 2007) (“[A] grant of summary judgment is appropriate only when (1) there is no genuine issue with regard to the material facts ..., and (2) based on undisputed facts, 'the moving party is entitled to a judgment as a matter of law."') (quoting TeNN. R. CIV. P. 56.04)).

184. Cf. Samuel R. Gross \& Kent D. Syverud, Don't Try: Civil Jury Verdicts in a System Geared to Settlement, 44 UCLA L. REV. 1, 60 (1996) ("The trials that occur, nonetheless, are primarily in cases in which the parties remain so far apart in their predictions of the decision on liability that they are willing to gamble on a jury's notoriously unpredictable verdict."); Peter Toll Hoffman, Valuation of Cases for Settlement: Theory and Practice, J. DISP. RESOL. 1, 2 (1991) ("[I]f . . a plaintiff values a case too high or the defendant too low, settlement becomes difficult or impossible. At a minimum, this prolongs negotiations and unnecessarily consumes the parties' and lawyers' time and resources. At worst, matters that should have been settled proceed to trial, placing heavy burdens on the court system and the parties."). 
disputes regarding the valuation of business interruption losses under the existing case law are unpredictable. ${ }^{185}$

Further, if a dispute arising from a contract (e.g., the insurance policy in this instance) has to be tried because the outcome of a trial is unpredictable, then one of the principal purposes of the contract also has failed. In addition to allowing the parties to memorialize their respective obligations, one of the principal purposes of contracts is to allow the parties to predict the results in the event of a breach by one of the parties. ${ }^{186}$ The necessity of a trial in a breach of contract dispute suggests that the predictive power of the contract, in this situation standard form policy language, is poor.

In short, if a case has to be tried, then a greater burden is placed on the legal system because the case has to proceed through discovery, motions practice, and trial at great expense to the parties, courts, and jurors. ${ }^{187}$ Consequently, an interpretation of policy language that unnecessarily results in trials is costly to the legal system; and thus, the policy language or the interpretation of it, should be changed.

\section{B. How Business Interruption Losses Should be Valued Under the Existing Policy Language}

185. See supra Part III.C.

186. Michael Hunter Schwartz \& Denise Riebe, Contracts: A Context and Practice CASEBOOK 5 (2009) (“[P]redictability promotes our free market economy by providing certainty for those involved in exchanging goods and services. If a merchant knows the legal consequences of her negotiating efforts or of the language she selects for her contracts, she can act accordingly. This predictability encourages people to enter into contracts, secure in the knowledge that those contracts will be enforced."); Eric A. Posner, A Theory of Contract Law Under Conditions of Radical Judicial Error, $94 \mathrm{Nw}$. U. L. REV. 749, 751 (2000) ("Long-term contracts raise a straightforward, but seemingly intractable problem: in the long term events are so hard to predict, that parties will not be able to allocate future obligations and payments in a way that maximizes the value of their contract.").

187. See, e.g., Ehrheart v. Verizon Wireless, 609 F.3d 590, 595 (3d Cir. 2010) ("Settlement agreements are to be encouraged because they promote the amicable resolution of disputes and lighten the increasing load of litigation faced by the federal courts. In addition to the conservation of judicial resources, the parties may also gain significantly from avoiding the costs and risks of a lengthy and complex trial.") (citation omitted); Murchison v. Grand Cypress Hotel Corp., 13 F.3d 1483, 1486 (11th Cir. 1994) ("We favor and encourage settlements in order to conserve judicial resources."); Miller v. State Farm Mut. Auto. Ins. Co., 155 P.3d 1278, 1281 (Mont. 2007) ("The declared public policy of this State is to encourage settlement and avoid unnecessary litigation ... Settlement eliminates cost, stress, and waste of judicial resources."). 
1. Applying the Rules of Policy Interpretation to Loss Valuation Language

Under the existing rules of policy interpretation, the postcatastrophe economic conditions should be considered when they favor the policyholder and ignored when they do not. ${ }^{188}$ Heads the policyholder wins, tails the insurer loses. How can that be right? Simply stated, the existing valuation language in business interruption policies is ambiguous. Thus, the language should be construed in favor of policyholders because insurers drafted it. ${ }^{189}$

Consider again the relevant policy language that states how a business interruption loss should be calculated:

[D]ue consideration shall be given to the experience of the business before the date of the damage or destruction and to the probable experience thereafter had no loss occurred. ${ }^{190}$

No formula for calculating business interruption losses is set forth. Nor does the language state how one should determine what the policyholder's "probable experience thereafter" would have been. Because the policy is silent on that issue, it is open to multiple interpretations. The policyholder may think its "probable" experience was going to be great because it had some great marketing ideas it had intended to implement. Should the policyholder's marketing ideas be part of the loss equation? If so, who and how do you value them? The policyholder also may have been projecting growth in its industry or had a new product it planned to introduce that it expected would be well received by the market. Are these factors that should be part of the loss equation under this policy language? The policy does not address such matters. To the contrary, the language is intentionally open-ended and vague.

Similarly, what does the phrase "had no loss occurred" mean? Does it mean: (1) had the catastrophe not occurred, (2) had the

188. See supra Part III.

189. See supra Part III.A.

190. Finger Furniture Co. v. Commonwealth Ins. Co, 404 F.3d 312, 314 (5th Cir. 2005). 
interruption of the policyholder's business not occurred (but ignore whether the catastrophe changed the demand for the policyholder's services or product), or (3) had the business interruption of the policyholder not occurred (but consider the impact the catastrophe had on the demand for the policyholder's services or product)? It is unclear what the answers to these questions are under the existing policy language. Thus, because it is open to multiple reasonable interpretations, the language is ambiguous.

These ambiguities are highlighted by the fact that courts have interpreted the same or similar business interruption loss valuation policy language and reached opposite conclusions regarding its meaning. ${ }^{191}$ On the one hand, the Fifth Circuit, for example, has interpreted the language to only allow for the consideration of the policyholder's historical financial information when valuing the loss. 192 On the other hand, the state courts in Louisiana have interpreted the language to allow for the consideration of post-catastrophe economic conditions when valuing the loss. ${ }^{193}$ When two conflicting interpretations are both reasonable, the policy language must be ambiguous. $^{194}$

Hornbook insurance law dictates that ambiguous policy language should be construed in favor of the policyholder and against the insurer. ${ }^{195}$ That means the post-catastrophe economic conditions should be considered if they are favorable to the policyholder. If the post-catastrophe economic conditions are unfavorable to the policyholder, then they should not be considered.

Further, the reasonable expectations doctrine also dictates that the post-catastrophe economic conditions should not be considered if the demand for the policyholder's products or services was negatively impacted by the catastrophe. ${ }^{196} \mathrm{~A}$ policyholder does not reasonably

191. See supra Parts II.A. and II.B.

192. Finger Furniture, 404 F.3d at 314.

193. See, e.g., Sher v. Lafayette Ins. Co., 973 So. 2d 39, 57 (La. Ct. App. 2007).

194. Bonner v. United Servs. Auto. Ass'n, 841 S.W.2d 504, 506 (Tex. Ct. App. 1992).

195. See supra Part III.A.

196. The reasonable expectations doctrine does not, however, dictate that the post-catastrophe economic conditions be considered if it would result in the policyholder receiving a windfall. See discussion supra Part III.B. In most contexts, policyholders will be hard pressed to credibly argue that 
expect to find itself in a situation where its business has been interrupted but no "loss" has occurred for insurance purposes simply because the area near its business also was destroyed and thus there is little or no demand for the policyholder's services or products postcatastrophe. A policyholder reasonably expects that, after paying premiums for business interruption insurance, ${ }^{197}$ it will be paid something when its business is interrupted. ${ }^{198}$ If the policy language were construed in such a way that the post-catastrophe conditions would be considered in situations where there was little or no demand for the policyholder's services or products due to the catastrophe (and thus, according to some insurers, no business interruption loss actually occurred), then the reasonable expectations of the policyholder would not be fulfilled. Indeed, no policyholder would reasonably expect that if a disaster destroys its business and the area near its business, then its insurance would become worthless. To the contrary, one of the primary reasons a policyholder purchases insurance such as business interruption insurance is to cover losses caused by disasters.

Again, Hurricane Katrina is a good example to illustrate the point. Many of the policyholders' restaurants were profitable before the hurricane. ${ }^{199}$ Then, there was an interruption in their businesses caused by the hurricane. In such circumstances, the policyholders reasonably expected they would be covered. Indeed, why would a policyholder whose business is located in a tourist town on the Gulf Coast, which is known for selling a drink called "the Hurricane,",200 buy business interruption insurance if the insurance would not cover

they reasonably expected their business interruption insurance would provide recoveries greater than their historical earnings simply because a disaster occurs. Id.

197. Insurers, of course, make money by collecting more in premiums than they pay in claims and by investing the premiums until claims are paid. Eliot Martin Blake, Rumors of Crisis: Considering the Insurance Crisis and Tort Reform in an Information Vacuum, 37 EMORY L.J. 401, 422-23 (1988) ("Insurers do not simply hang onto premiums, of course; they invest them for the time period between payment of premiums and payment of losses.... The role of investment income in the [insurance] industry is particularly important. Studies have concluded that investment income allows the industry to remain profitable as a whole even with significant negative underwriting losses.").

198. See supra Part III.B.

199. See McCulley, supra note 174.

200. Keith I. Marszalek, Home of the "Hurricane" Pat O'Brien's Turns 75 This Week, Nola.com (Nov. 30, 2008, 4:47 PM), http://blog.nola.com/anguslind/2008/11/pat_os_turns_75_this_week.html. 
the loss of earnings caused by hurricanes that prevent tourists from going to the area?

Similarly, the policy interpretation rule which provides that all of the provisions of a policy should be interpreted in a harmonious way that gives effect to the primary purpose of the insurance also dictates a result favorable to policyholders. ${ }^{201}$ The purpose of business interruption insurance is to transfer the risk of a loss of earnings due to business interruptions from the policyholder to the insurer. ${ }^{202}$ Indeed, business interruption insurance's primary purpose is to maintain the policyholder's revenue stream during periods of interruption such that the policyholder will be returned to the same position it would have been had no business interruption occurred. ${ }^{203}$ Thus, with these primary purposes of the insurance in mind, the valuation language should be interpreted in a way that ensures the policyholder will be made whole, which means the post-catastrophe economic conditions should not be considered if doing so would result in the policyholder effectively becoming uninsured for its loss of earnings following a catastrophe.

\section{Analyzing the Loss Valuation Policy Language as a "Defective} Product"

In recent years, some scholars have advanced the theory that because policies are non-negotiated contracts of adhesion with standardized language drafted by insurers and are sold on a take-itor-leave-it basis, policies should be viewed as akin to products or "things" rather than simply contracts. ${ }^{204}$ This theory is further supported by the fact that policyholders often do not receive a copy of the policy itself until many months after it was purchased and they rarely read the many pages and terms of the policy when it finally is received. ${ }^{205}$ Consequently, most policyholders are not even aware of

201. See supra Part III.C.

202. See supra Part I.A.

203. See supra note 6.

204. See, e.g., Schwarcz, supra note 153, at 1389; Jeffrey W. Stempel, The Insurance Policy as a Thing, 44 TORT TRIAL \& INS. PRAC. L.J. 813, 835 (2009).

205. See KEETON \& WIDISS, supra note 151, § 6.3, at 634; Kenneth S. Abraham, Four Conceptions of 
what the specific language is in the policies. ${ }^{206}$ Even policyholders who attempt to review the pages and pages of terms and conditions set forth in the policy likely do not understand them due to the length and complexity of the language used. ${ }^{207}$

Further, the insurance industry routinely refers to insurance policies as "products" that are researched, designed, marketed, and sold like manufactured goods. ${ }^{208}$ Similarly, the purchasers of insurance also consider insurance a "good" and brand loyalty for insurance products is very high. ${ }^{209}$

When a policy is viewed as a product, the "reasonable expectations" doctrine and contra proferentem can be understood as judicially created contractual interpretation tools that courts apply in order to attempt to ensure that policyholders actually receive the product they thought they were purchasing. ${ }^{210}$ Instead of applying those interpretive tools to what can be viewed as a contract in name only, policies instead can be viewed as products. As a product, the question to be answered is whether the product that was sold is defective because it fails to perform as reasonably expected by the purchaser of the product - the policyholder. Of course, if a product is defective, then the seller of the product - the insurer-is responsible for any harm or damage caused by the product. ${ }^{211}$

In the business interruption context, when a policyholder purchases a business interruption policy it reasonably expects to be paid the full amount of its loss less the deductible in the event that its business is interrupted. If the loss valuation language allows the insurer to pay nothing or less than the full amount of the loss in the event of a business interruption, then the policy is defective from the policyholder's perspective. Consequently, the policyholder is injured

\footnotetext{
Insurance, 161 U. PA. L. REV. 653, 660 (2013).

206. KEETON \& WIDISS, supra note 151, § 6.3, at 634; Abraham, supra note 205, at 660 .

207. KEETON \& WIDISS, supra note 151, § 6.3, at 634; Abraham, supra note 205, at 660.

208. Stempel, supra note 204, at 831.

209. Id. at 832 .

210. Id. at 831

211. Restatement (ThiRd) OF Torts: Products Liability $\S 1$ (1998) (“One engaged in the business of selling or otherwise distributing products who sells or distributes a defective product is subject to liability for harm to persons or property caused by the defect.").
} 
by the defective product in so far as it suffers an uncompensated loss and cannot retroactively buy an insurance policy to cover the unreimbursed portion of the loss. Under strict liability principles applicable to injuries caused by defective products, the seller of the defective product - the insurer - is liable for the injuries caused by its product. $^{212}$ Thus, the insurer would be liable to the policyholder, under a products liability theory, for the amount of the policyholder's loss that the policy does not cover.

Does such an approach lead to a different result than when the reasonable expectations doctrine and contra proferentem are applied to the loss valuation language? No. Under both approaches, the insurer is legally responsible for ensuring that the product it sellsthe policy-fulfills the reasonable expectations of the purchaser of the product regarding the performance of the product. Considering policies as products, instead of contracts, however, is another way of analyzing the issue that confirms accuracy of the result under the traditional rules of policy interpretation.

\section{Proposed Loss Valuation Formulas That are Based Upon the} Original Purpose of Business Interruption Insurance and Which Provide Consistent, Predictable Results and the Efficient Resolution of Claims

In this part, two proposed formulas for calculating business interruption losses are set forth and the public policy considerations associated with the payment of business interruption losses are analyzed. These proposals initially are intended for insurers, the drafters of policy language, because redrafting the policy language to incorporate either one of the proposals should eliminate many, if not all, of the disputes addressed in this Article that exist under the current policy language. ${ }^{213}$ If insurers fail to adopt one of the proposals, however, then courts and legislatures should act to ensure that the way business interruption losses are calculated changes.

212. Id. $\S 1 \mathrm{cmt}$. a.

213. See supra Part II. 
1. A Stated Daily Loss Value Set Forth in the Policy or Only the

Policyholder's Prior Three Years of Historical Earnings and

Expenses Should be Used When Valuing Business Interruption

Losses

Simply stated, to eliminate the problems with the existing policy language discussed in this Article, either a stated daily loss value or only the prior three years of the policyholder's historical earnings and cost information should be used to calculate business interruption losses. More specifically, the policies should contain a stated daily loss value for business interruption losses, just as the original "use and occupancy" policies did for lost rents. ${ }^{214} \mathrm{~A}$ daily loss value is the amount of loss a business suffers each day its business's operations are suspended. ${ }^{215}$ During the annual policy renewal process, a policyholder provides a business interruption loss projection to the insurer's underwriters that is based upon the policyholder's current budget, revenue, and cost data that the insurer then uses to: (1) evaluate the insured risk, (2) calculate a daily loss value, and (3) in part, establish the amount of the premium. ${ }^{216}$ These same daily loss value figures could and should be used to calculate the loss in the event of a business interruption. Indeed, under disability insurance, which is analogous to business interruption insurance in that it insures a person for the income the person loses during time periods when the person is unable to work due to injury or illness, the amounts to be paid to the policyholder in the event of a disability are expressly stated in the policy and usually are a percentage of the policyholder's income. $^{217}$

Using a stated daily loss value or a three-year time period of historical earnings and costs would eliminate arguments about whether earnings and costs were trending up or down before the business interruption or whether the policyholder's recent results

214. TORPEY, LENTZ \& MELTON, supra note 1, at 6 .

215. Id. at 5 .

216. Johnson \& O'Toole, supra note 18, at 65 (discussing how most policyholders are required to submit business interruption values as a part of the initial underwriting, and insurers will use the values to measure, inter alia, basis for annual premiums, deductibles, limits, and daily value deductibles).

217. Kenneth S. Abraham, Insurance LaW And Regulation 430 (5th ed. 2010). 
were anomalous. ${ }^{218}$ Using a stated daily loss value or a three-year time period of historical financial results also would account for the state of the economy without the necessity of speculating about what the future would have held. As the Fifth Circuit has stated, "the strongest and most reliable evidence of what a business would have done had the catastrophe not occurred is what it had been doing in the period just before the interruption." 219 The loss valuation policy language should be changed to reflect that reality.

The cost savings for the legal system should be significant under either of these proposals. Under these proposals, the parties would not need to hire experts to debate the state of the economy. Nor would they need to hire experts to opine on the industry trends for the policyholder's business. Instead, the loss calculation would be a simple mathematical calculation in which the number of days the business was interrupted is multiplied by either the daily loss value contained in the policy or the historical average daily earnings and expenses. Thus, instead of hiring expensive forensic accountants to fight about the policyholder's "probable" experience during the period of interruption, the policyholder or its accountant easily could do the calculation. Insurers also could easily confirm the accuracy of the calculation.

Under these approaches, courts and juries similarly would not need to grapple with the issue of whether the policyholder has proven what "would have happened" to a "reasonable degree of certainty.",220 What would have happened is moot. The past becomes the proxy for the future and it would be expressly stated in the policy.

These proposals also would eliminate the windfall gain or unfairly low or non-existent claim payments that now occur when the

218. This proposal would not be appropriate, however, for new businesses or product lines that open during the policy period or do not have a historical record of earnings and costs. In such circumstances, an industry average for a comparable business or line of business for the prior three-year time period should be used. Of course, the policyholder may have done better or worse than the industry average, but using the industry average should eliminate the disputes about the state of the economy, industry trends, and what the policyholder "would have done" in the hypothetical way in which such claims are analyzed today.

219. Finger Furniture Co. v. Commonwealth Ins. Co., 404 F.3d 312, 314 (5th Cir. 2005).

220. See supra Part II.D. 
economic conditions post-catastrophe are considered for purposes of calculating the loss. ${ }^{221}$ The policyholder would not get a windfall benefit due to the increased demand for its product or services that is created by the catastrophe in some circumstances or an unfairly low or non-existent insurance payment when demand decreases in other circumstances. Instead, the policyholder would receive its continuing expenses and exactly what it had been earning before the catastrophe occurred. Using a daily loss value or only historical financial information would put the policyholder in the same position the parties agreed at the time of underwriting that the policyholder most likely would have been if the catastrophe had not occurred, which is the very purpose of business interruption insurance.

Does the policyholder receive precisely what it would have received had the catastrophe not occurred under this proposal? It is impossible to know. One cannot predict the future with a high degree of accuracy, which is why the "reasonable degree of certainty" evidentiary standard is misplaced when attempting to value business interruption insurance losses under the existing policy language. ${ }^{222}$ Nor can one create an accurate and complete picture of what a hypothetical world would have looked like in the absence of a catastrophe. The policyholder's past, however, is known. Using the policyholder's past as a proxy for the policyholder's future provides a fair outcome for both the policyholder and the insurer in a situation where one hundred percent accuracy is not possible.

Using a stated daily loss value or only the policyholder's revenue and cost data for the three-year time period immediately preceding the loss when valuing the loss also should lead to consistent and predictable outcomes. Although insurers may be required to pay claims they might otherwise have chosen to litigate under the vague valuation provisions currently used in their policies, the outcome of disputes in which an insurer chooses to contest the payment of a claim under these proposals should be fairly predictable because the dispute would be decided under a bright line rule. Consequently,

221. See supra Part II.B.

222. See supra Part IV.A.1. 
insurers would be incentivized not to litigate claims they likely would lose in order to avoid incurring wasteful litigation costs.

In addition to reducing the incentive to litigate, this predictability in the outcome of disputes would be beneficial to insurers as well because it would allow them to reserve for claims more accurately and to establish with more certainty the amount of premiums needed to cover claims and be profitable. ${ }^{223}$ Thus, this predictability also should result in cost savings for insurers.

Using a stated daily loss value or only the policyholder's historical revenue and cost data when valuing business interruption losses also should lead to a more cost-effective claims adjustment process. By using a bright line formula, the parties should not need to retain experts to engage in hypothetical debates regarding what would have happened had the catastrophe not occurred. Nor should the parties need to debate the impact the current state of the economy would have on the policyholder's hypothetical earnings and costs. Nor, in most cases, should the courts and parties even need to conduct trials regarding the amount of the loss. Further, to the extent the parties cannot agree on the amount of the loss, the court in many instances nonetheless should be able to resolve the dispute on a motion for summary judgment because, assuming the facts are not in dispute, resolution of the dispute would be a question of law. The judge would only need to apply the daily loss value or the average historical earnings and expenses to the number of days the policyholder's business was interrupted in order to determine the amount of the covered loss. ${ }^{224}$ Thus, few trials should be needed, and,

223. See, e.g., Sanchez v. Lindsey Morden Claims Servs., Inc., 84 Cal. Rptr. 2d 799, 802 (Cal. Ct. App. 1999) ("Insurance is a highly uncertain and risky endeavor, because it requires accurate predictions about the occurrence and cost of future events. Insurers are able to define and limit the risks, and to set premium levels commensurate with the risks, using complex and nuanced contracts (policies)."); Nancy R. Page, Risky Business: Consumer Protection in the Insurance Industry, 23 HARV. J. ON LEGIS. 287, 291 (1986) ("Predicting claims and pooling risks is the business of insurance. When accurate prediction is no longer possible, some liability markets become theoretically too risky for insurance.").

224. See, e.g., Private Bank \& Trust Co. v. Progressive Cas. Ins. Co., 409 F.3d 814, 816 (7th Cir. 2005) ("We are presented with a question of insurance policy interpretation, which is a question of law ....”); In re Frederick Petroleum Corp., 912 F.2d 850, 852 (6th Cir. 1990) (noting that a question of policy interpretation is a question of law); Farmers Home Mut. Fire Ins. Co. v. Bank of Pocahontas, 129 S.W.3d 832, 835 (Ark. 2003) ("Whether the policy language is ambiguous is a question of law to be resolved by the court."); Penzer v. Transp. Ins. Co., 29 So. 3d 1000, 1005 (Fla. 2010) ("This case 
in most cases, the parties should be able to resolve the claims without even retaining experts or involving the courts.

\section{Public Policy Considerations}

Public policy also favors using a stated daily loss value or only the historical earnings and costs of the policyholder when valuing business interruption losses. As an initial matter, no obvious public policy considerations favor the haphazard approach to valuing business interruption losses that currently exist. Nor would the typical theoretical concerns of insurers, such as adverse selection and moral hazard, be implicated if a stated daily loss value or only historical earnings and cost information were used. ${ }^{225}$

Adverse selection in the insurance context is "the disproportionate tendency of those who are more likely to suffer losses to seek insurance against those losses." 226 Insurers already face adverse selection issues in the context of business interruption insurance because businesses that are located in areas prone to floods, hurricanes, or tornadoes naturally would be more incentivized to purchase business interruption insurance. ${ }^{27}$ Changing the loss valuation language, as proposed in this Article, however, should not impact that problem positively or negatively.

Moral hazard is the tendency of a policyholder to take fewer precautions when insured. ${ }^{228}$ Another commentator has defined the

presents a question of insurance policy interpretation, which is a question of law ....").

225. Some critics of the concepts of adverse selection and moral hazard have argued that these alleged threats are overblown and that the exclusions designed to address them are overly broad. See, e.g., Tom Baker, On the Genealogy of Moral Hazard, 75 TEX. L. REV. 237, 240 (1996); Peter Siegelman, Adverse Selection in Insurance Markets: An Exaggerated Threat, 113 YALE L.J. 1223, 1234 (2004).

226. Kenneth S. Abraham \& Lance Liebman, Private Insurance, Social Insurance, and the Tort Reform: Toward a New Vision of Compensation for Illness and Injury, 93 COLUM. L. REV. 75, 102 n.82 (1993). See also MARK S. DORFMAN, INTRODUCTION TO RISK MANAGEMENT AND INSURANCE 95 (8th ed. 2005) (describing the difficulty underwriters have in determining the risk of insuring persons in poor health); EMmETT J. VAughan \& THERESE VAughan, FundAMENTALS OF RISK AND INSURANCE 21-22 (8th ed. 1999) (noting how adverse selection accumulates bad risks, which disrupts underwriters' predictions about future losses).

227. Abraham \& Liebman, supra note 226, at 103; VAUGHAN \& VAUGHAN, supra note 226, at 21-22. 228. Adam F. Scales, The Chicken and the Egg: Kenneth S. Abraham's "The Liability Century," 94 VA. L. ReV. 1259, 1263 (2008) (reviewing Kenneth S. Abraham, The Liability Century: Insurance AND TORT LAW FROM THE PROGRESSIVE ERA TO 9/11 (2008)) ("Moral hazard is the tendency to take fewer precautions in the presence of insurance. Adverse selection is the tendency of 
concept of "moral hazard" as a situation where "[a] person ... deliberately causes a loss ... [or] exaggerates the size of a claim to defraud an insurer."229

As a practical matter, there should be little concern by insurers that policyholders would attempt to artificially increase their historical earnings in anticipation of suffering losses due to events like hurricanes, tornadoes, and floods. Indeed, doing so would lead to higher premiums that the policyholders actually would hope they never recouped because the last thing a policyholder running a profitable business hopes for is that a hurricane, tornado, or flood will hit it. Further, even if policyholders were inclined and able to inflate the daily loss value, because policyholders do not create or control catastrophic events such as hurricanes, tornadoes, and floods, policyholders would not have the ability to cause the business interruption losses that most commonly occur. Consequently, moral hazard concerns would not be created by changing the loss valuation language in accordance with this proposal.

Nonetheless, because daily loss values for business interruptions are established at the time of underwriting, insurers would be free to confirm or contest the accuracy of the cost and revenue numbers that underlie those calculations before accepting a premium for the policy. ${ }^{230}$ Moreover, because such numbers are annually updated during the policy renewal process, there is little risk of the numbers becoming outdated. ${ }^{231}$ Thus, any unlikely moral hazard concerns of the insurer could and should be resolved before the policy is placed.

In addition, insurance fills the socially important and desirable role of protecting the limited assets of individuals and business owners against catastrophic losses by spreading and transferring the risk of such losses to well-capitalized insurers. ${ }^{232}$ Indeed, insurance is

riskier people to gravitate towards unsuspecting insurance pools, eventually raising premium rates and causing less risks people to exit. A great deal of insurer behavior is designed to combat, or at least manage, these problems.").

229. DORFMAN, supra note 226, at 480 .

230. See supra note 216 .

231. Id.

232. Jeffrey W. Stempel, The Insurance Policy as Social Instrument and Social Institution, 51 WM. \& MARY L. REV. 1489, 1502 (2010). 
integral to people's lives and the conduct of business in modern industrial economies. ${ }^{233}$ Without insurance, people and businesses simply cannot function in today's world. For example, anyone who wants to purchase a house using a bank to finance the mortgage is required to have homeowners insurance in an amount adequate to cover the mortgage. ${ }^{234}$ Anyone who wants to drive a car must have auto insurance. ${ }^{235}$ Most states require businesses to have worker's compensation insurance. ${ }^{236}$

Similarly, if someone wants to live or do business in areas prone to hurricanes, tornadoes, and floods, they need insurance to protect their homes and businesses. Without it, they risk bankruptcy with each passing storm. Further, if the business interruption insurance that is actually purchased by a business owner does not cover the business's loss during a period of interruption, then the primary purpose of the insurance has failed and the business owner and society in general are in a worse position. Consequently, the adoption of either one of these proposals would ensure that business interruption insurance fulfills its important role in society.

The long-standing public policy of enforcing contracts also favors the full payment of business interruption losses under insurance policies. ${ }^{237}$ Indeed, as one court correctly noted, in the area of insurance law, "[t]here is more than one public policy. One such policy is that an insurance company which accepts a premium for covering all liability for damages should honor its obligation." "238 Insurers draft the policies, which are then sold on a take-it-or leave-it basis. ${ }^{239}$ As drafters of the language contained in insurance policies, at a minimum, insurers should state in the policies, in clear terms, the specific way that business interruption losses will be valued. They have failed to do so and public

\footnotetext{
233. Id. at 1497.

234. $I d$.

235. Id. at $1497-98$.

236. Id. at 1498.

237. See, e.g., Nw. Nat'l Cas. Co. v. McNulty, 307 F.2d 432, 444 (5th Cir. 1962) (Gewin, J., concurring) (noting that public policy favors the enforcement of contracts); Union Camp Corp. v. Cont'l Cas. Co., 452 F. Supp. 565, 568 (S.D. Ga. 1978) ("Exercise of the freedom of contract is not lightly to be interfered with. It is only in clear cases that contracts will be held void as against public policy.").

238. Creech v. Aetna Cas. \& Sur. Co., 516 So. 2d 1168, 1174 (La. Ct. App. 1987).

239. See supra note 9.
} 
policy, as well as the rules of policy interpretation, dictates that insurers should not be given the benefit of the doubt in such circumstances in their quest to maximize their own profits. ${ }^{240}$

Consequently, in light of the fact that the purpose of business interruption insurance is to protect the policyholder's earnings in the event business operations are interrupted, ${ }^{241}$ public policy favors interpreting or using a loss calculation formula that ensures policyholders' losses will be paid in full in the event of catastrophes. To do otherwise creates the very real possibility that policyholders could lose the reasonably expected coverage they bought, which expectation is consistent with the purpose of insurance generally and business interruption insurance specifically.

Basic principles of fairness also dictate this result. Insurers should not be allowed to inconsistently apply the nebulous policy language they themselves drafted in a coverage-minimizing or coveragedefeating manner depending upon whether the post-catastrophe economic conditions favor the policyholder. Nor should policyholders be required to prove the amount of their losses to a reasonable degree of certainty when such calculations are based upon a hypothetical world in which no interruption of the policyholder's business occurs. In short, public policy favors an interpretation or use of a valuation provision that provides consistent, fair results. Using a stated daily loss value or only the three prior years of the policyholder's revenue and cost data will provide consistent and fair results.

Thus, insurers should redraft the valuation language in accordance with either of the proposals discussed in this Article. If they fail to do

240. Sch. Dist. for City of Royal Oak v. Cont'l Cas. Co., 912 F.2d 844, 849 (6th Cir. 1990) ("Had the company wished to exclude coverage for intentional religious discrimination in employment, it could and should have said so."); Union Camp, 452 F. Supp. at 568 ("Continental and other insurers which have issued policies containing such clauses have not up to now conceived that they were violating public policy by writing insurance policies insuring against losses resulting from discriminatory employment practices.”); Ranger Ins. Co. v. Bal Harbour Club, Inc., 509 So. 2d 945, 947 (Fla. Dist. Ct. App. 1987) (citing Union Camp, 452 F. Supp. at 567-68); Univ. of Ill. v. Cont'l Cas. Co., 599 N.E.2d 1338, 1350-51 (Ill. App. Ct. 1992) ("[T]he insurer is an informed contracting party with no inferiority in bargaining position and should not be allowed to escape from the contract it freely entered into ... . This court will not rewrite the ... policy to create an exclusion."); Indep. Sch. Dist. No. 697 v. St. Paul Fire \& Marine Ins. Co., 495 N.W.2d 863, 868 (Minn. Ct. App. 1993) ("The carrier is, of course, free to expressly provide an exclusion for such conduct in the future.").

241. See supra note 6 . 
so, then the courts should strictly construe the ambiguities in the existing language against insurers. If neither insurers nor courts are able to remedy the current problems, then legislatures need to enact statutes that dictate how business interruption losses will be valued. Indeed, history is replete with examples of legislatures acting to reverse unsatisfactory decisions by courts ${ }^{242}$ or insurers' refusals to pay certain types of claims such as fire loss claims after the 1906 earthquake in San Francisco ${ }^{243}$ or to provide health insurance to people who are sick. ${ }^{244}$ The valuation of business interruption losses may be another area of insurance law in which legislatures need to dictate the right solution if insurers and courts fail to do so. Of the two proposals set forth in this Article, the author submits that the easiest and fairest to apply would be to use a stated daily loss value because it is a number that is agreed to by the parties at the time the policy is purchased.

\section{CONCLUSION}

Business interruption losses can be enormous when a catastrophe or disaster occurs. How such losses are valued for insurance purposes can be the difference between a business surviving or failing. The loss valuation language currently used in business interruption policies provides almost no guidance regarding how such losses should be valued. ${ }^{245}$ This vacuum has resulted in unnecessary

242. CAL. INS. CODE $\S 10113.5$ (West 2013) (statute provides that a life insurance policy is void "if an impostor is substituted for a named insured in any part of the application process ..." after the Supreme Court of California, in Amex Life Assurance Co. v. Superior Court, 930 P.2d 1264 (Cal. 1997), allowed a beneficiary to recover under a life insurance policy where the insured was HIV positive but sent an imposter to do the medical exam required in order to procure the policy); Christopher C. French, Construction Defects: Are They "Occurrences"?, 47 GoNZ. L. REv. 1, 27 n.91 (2011) (noting that several states have passed statutes which mandate that construction defects are covered "occurrences" under commercial general liability policies in light of certain court decisions that held construction defects are not occurrences).

243. French, supra note 142, at 217.

244. See generally Patient Protection and Affordable Care Act, Pub. L. No. 111-148, 124 Stat. 119 (2010), amended by Healthcare and Education Reconciliation Act, Pub. L. No. 111-152, 124 Stat. 1029 (2010) (requiring, among other things, insurers to sell health insurance to people with preexisting health conditions and disallowing insurers to cancel or refuse to renew policies of sick people).

245. See supra Part I.B. 
litigation, the inefficient resolution of claims, and conflicting court decisions in which policyholders receive windfalls in some cases and nothing in other cases under similar fact patterns and policy language. ${ }^{246}$

Under the existing rules of policy interpretation, any ambiguities in the policy language should be resolved in favor of the policyholder when a claim is presented, and the reasonable expectations of the policyholder should be fulfilled. ${ }^{247}$ Thus, because the existing loss valuation policy language is ambiguous, one solution to the problem of unfair loss valuations would be for courts to properly apply the rules of policy interpretation to the existing policy language, which should lead to inconsistent results that consistently favor the policyholder. $^{248}$

This Article, however, proposes better solutions. Instead of the ad hoc approach that currently exists, a better approach would be to use only the prior three years of the policyholder's historical financial revenue and cost data to value such losses. An even better approach, however, would be to use the daily loss value that already is agreed to by the policyholder and insurer annually during the policy renewal underwriting process when the policy is purchased. Under either approach, the payment of business interruption losses would be consistent, fair, and predictable for both insurers and policyholders. Further, under both approaches, litigation would be unnecessary for most business interruption loss claims, which should be a welcome result for everyone ... except litigators and forensic accountants.

246. See supra Part II.

247. See supra Part III.

248. See supra Part IV.B. 